3

4 5 6

8

9

10

\title{
Chemical and Isotopic Fractionation of Lead in the surface soils of Egypt
}

\author{
Waleed H. Shetaya ${ }^{1,{ }^{*}}$, Ezzat R. Marzouk ${ }^{2}$, Elham F. Mohamed ${ }^{1}$, Elizabeth H. Bailey ${ }^{3}$, \\ Scott D. Young ${ }^{3}$ \\ ${ }^{1}$ Air Pollution Research Department, Environmental Research Division, National Research Centre, 33 \\ El-Bohouth St., Dokki, Giza 12622, Egypt \\ 2Division of Soil and Water Sciences, Faculty of Environmental Agricultural Sciences, Arish University, \\ North Sinai, 45516, Egypt \\ ${ }^{3}$ Division of Agricultural and Environmental Sciences, School of Biosciences, University of \\ Nottingham, Sutton Bonington, Leicestershire LE12 5RD, UK \\ *Corresponding Author: Waleed H. Shetaya, +201012632019, wh.shetaya@nrc.sci.eg; \\ waleed.shetaya@outlook.com
}




\section{Abstract}

40 Chemical fractionation via sequential extraction (SEP) combined with isotopic analysis of $\mathrm{Pb}$ was used

41 to investigate the origins and reactivity of $\mathrm{Pb}$ in 66 topsoil samples collected from 12 different locations in Egypt. The total soil Pb concentrations (TPb) covered a wide range $\left(\sim 80-16,000 \mathrm{mg} \mathrm{kg}^{-1}\right)$, but were only elevated in four industrial and urban locations within Cairo and Alexandria. In all the other locations values of $\mathrm{TPb}$ were generally low and were close to the average crustal $\mathrm{Pb}$ concentration of $14 \mathrm{mg} \mathrm{kg}^{-1}$. The largest $\mathrm{Pb}$ fraction in all soils, with the exception of two industrial locations, was the 'residual' fraction ( $38-63 \%$ of $\mathrm{TPb}$ ) followed by $\mathrm{Pb}$ bound to 'organic' and 'metal oxide' phases. The $\mathrm{Pb}$ isotopic signatures $\left({ }^{206} \mathrm{~Pb} / 207 \mathrm{~Pb}\right.$ vs $\left.{ }^{208} \mathrm{~Pb} / 207 \mathrm{~Pb}\right)$ of all samples in all SEP fractions were highly variable, suggesting a heterogeneous mix of $\mathrm{Pb}$ contamination sources; however, they aligned closely to a binary mixing line between geogenic and petrol $\mathrm{Pb}$ sources. There were similar patterns across all of the non-residual fractions with measureable data (F2 - F4) suggesting that the non-residual anthropogenic- $\mathrm{Pb}$ and geogenic- $\mathrm{Pb}$ have been assimilated into common pools within the soil. Binary and ternary source-apportionment models based on $\mathrm{Pb}$ isotopic ratios and abundances showed that the relative contribution of petrol- $\mathrm{Pb}$ and geogenic- $\mathrm{Pb}$ can be ascribed with reasonable certainty. However, the contribution of further sources can only be accounted for if the isotopic abundance of all end-members are known and are at the periphery of the soils dataset.

57 Keywords: 


\section{Introduction}

Lead $(\mathrm{Pb})$ is listed by the WHO as a chemical of major public health concern because of its high toxicity to living organisms (WHO, 2010). Long-term exposure of humans and animals to low levels of $\mathrm{Pb}$ through inhalation and/or ingestion may lead to a range of adverse clinical complications including neurological, cardiovascular and renal damage (Needleman and Bellinger, 1991). Geogenic Pb is composed of four stable isotopes: ${ }^{208} \mathrm{~Pb}(52 \%),{ }^{206} \mathrm{~Pb}(24 \%),{ }^{207} \mathrm{~Pb}(23 \%)$ and ${ }^{204} \mathrm{~Pb}(1 \%)$; the only primordial isotope is ${ }^{204} \mathrm{~Pb}$, while the others are the fission products of uranium and thorium (Komárek et al., 2008). Therefore, the isotopic composition of $\mathrm{Pb}$ varies between different geological sources and this can be used as a tool to identify sources of pollutant $\mathrm{Pb}$ and to study its environmental fate (Veysseyre et al., 2001).

The large scale industrialization and urbanization of Egypt since the 1950's, in addition to the common practice of open air incineration of agriculture and other waste (Mohamed et al., 2015), were associated with the emission of large amounts of pollutants (including $\mathrm{Pb}$ ) to the atmosphere. As a result, by the late 1980's and early 1990's Pb in the atmosphere of urban Egypt reached deleterious concentrations (Hassanien and Horvath, 1999, Nasralla and Ali, 1984, Shakour and El-Taieb, 1994). However, due to the introduction of the Environment Law in 1994 and the implementation of several environmental protection measures, such as relocating lead smelters and phasing out leaded petrol, the concentration of atmospheric $\mathrm{Pb}$ in urban Egypt reached safe levels by the end of the 1990's (Hassan et al., 2013, Hassanien et al., 2001, Rizk and Khoder, 2001, Safar and Labib, 2010). Nevertheless, most of the legacy anthropogenic- $\mathrm{Pb}$ which has been deposited on surface soils may not have been fully assimilated into the same soil fractions as geogenic- $\mathrm{Pb}$. The bioavailability and mobility of contaminant $\mathrm{Pb}$ is therefore difficult to predict and it may be transferred to food and fodder crops and surface or ground waters more readily than geogenic- $\mathrm{Pb}$.

Measuring total concentrations of heavy metals in soils may not always be a useful approach for risk assessment because, frequently, only a small proportion of soil metal is mobile under natural conditions (Tack and Verloo, 1995, Teutsch et al., 2001). It is therefore useful to estimate the labile, and potentially bioavailable, metal pool alongside the total concentration (Meers et al., 2007, Young et al., 2000). Sequential extraction protocols (SEP) have been used to investigate the chemical fractionation and 
potential availability of heavy metals in soils. Possibly the most established SEP is the one developed by Tessier et al. (1979) which provides a guide to the likely chemical form of metals in soil or the adsorption phases with which the metals are associated. In the Tessier SEP, five operational fractions are identified: (F1) Exchangeable (metal fractions desorbed due to changes in the ionic composition of soil solution), (F2) Bound to carbonates (metal fractions reactive to $\mathrm{pH}$ fluctuations), (F3) Bound to $\mathrm{Fe}$ and $\mathrm{Mn}$ oxides (fractions that can be released by reduction of oxides under low Eh conditions), (F4) Bound to organic matter (metal fractions released under strong oxidizing conditions), and (F5) Residual (metal fractions held within the crystal structure of soil minerals).

The main aim of this work was to assess the current reactivity of $\mathrm{Pb}$, and identify its origins, in Egyptian soils two decades after phasing out leaded petrol and implementing countermeasures to $\mathrm{Pb}$ pollution. This was achieved by studying the chemical fractionation and isotopic composition of $\mathrm{Pb}$ in some Egyptian surface soils and the soil properties likely to control them. A total of 66 soil samples that had been exposed to different degrees of $\mathrm{Pb}$ contamination were collected and characterized. Soil metals were chemically fractionated based on the SEP procedure of Tessier et al. (1979). The isotopic abundances of the four stable $\mathrm{Pb}$ isotopes were also measured in the SEP extracts by inductively coupled plasma mass spectrometry (ICP-MS). The objective was to assess the degree of assimilation of anthropogenic- $\mathrm{Pb}$ (mainly petrol- $\mathrm{Pb}$ ) and geogenic $\mathrm{Pb}$, into each soil $\mathrm{Pb}$ fraction (Shetaya et al., 2018). Moreover, multiple-sources models were used to try to identify the relative contribution of petrol, geogenic and industrial $\mathrm{Pb}$ sources, to different soil phases, based on their $\mathrm{Pb}$ isotopic signatures. 10

(1)

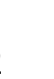

23




\section{Materials and Methods}

130

131

132

133

134

135

136

137

138

139

140

141

142

143

\subsection{Soil sampling}

Sixty six topsoil samples $(0-20 \mathrm{~cm})$ were collected, along a transect $0-100 \mathrm{~m}$ away from main roads, from 12 different locations in Egypt representing industrial, urban, agriculture and background sites (Table 1). Industrial locations included a cement factory (HE-I), inactive lead smelter (SH-I) and a major waste water treatment facility (CA-I). Urban soils were sampled around major motorways within the largest two urban conurbations in Egypt: Greater Cairo (CA-U and SH-U) and Alexandria (AX-U), in addition to Ismailia City (IS-U) and Assiut-Menya desert motorway (AM-U). Agriculture soils were collected from arable fields within Ismailia (IS-G) and Sharkia (SK-G) governorates. Reference (background) soils were sampled from 2 rural locations that were expected to have been exposed to minimal $\mathrm{Pb}$ deposition or discharge including sites in the Sinai Peninsula (SI-B) and Suez governorate (SZ-B). Soils were collected with a clean stainless steel trowel and sealed in plastic bags for transport.

Table 1. Sampling locations, codes and description. Letters I, U, G and B at the end of sample codes refer to the industrial, urban, agriculture and background nature of the sampling location, respectively.

\begin{tabular}{lllll}
\hline Site nature & Location & Code & $\begin{array}{l}\text { Number of } \\
\text { Soil Samples }\end{array}$ & Coordinates \\
\hline Industrial & Cairo - Helwan & HE-I (Cement Factory) & 4 & $29.83 \mathrm{~N}, 31.31 \mathrm{E}$ \\
& Cairo - Shubra & SH-I (Lead Smelter) & 4 & $30.11 \mathrm{~N}, 31.27 \mathrm{E}$ \\
& Cairo - Khanka & CA-I (Waste Water Treatment) & 4 & $30.20 \mathrm{~N}, 31.37 \mathrm{E}$ \\
Urban and & Cairo - Ring Road & CA-U & 10 & $30.17 \mathrm{~N}, 31.35 \mathrm{E}$ \\
Motorways & Alexandria & AX-U & 5 & $31.15 \mathrm{~N}, 29.97 \mathrm{E}$ \\
& Cairo - Shubra & SH-U & 8 & $30.14 \mathrm{~N}, 31.25 \mathrm{E}$ \\
& Ismailia & IS-U & 8 & $30.59 \mathrm{~N}, 32.27 \mathrm{E}$ \\
\multirow{5}{*}{ Agriculture } & Assiut - Minya & AM-U & 4 & $27.93 \mathrm{~N}, 30.57 \mathrm{E}$ \\
& Ismailia & IS-G & 4 & $30.68 \mathrm{~N}, 32.05 \mathrm{E}$ \\
& Sharkia & SK-G & 4 & $30.64 \mathrm{~N}, 31.70 \mathrm{E}$ \\
& Sinai & SI-B & 3 & $30.83 \mathrm{~N}, 34.14 \mathrm{E}$ \\
& Suez & SZ-B & 8 & $30.10 \mathrm{~N}, 32.57 \mathrm{E}$ \\
\hline
\end{tabular}

\subsection{Characterization of soil samples}

Soil samples were air dried at room temperature and then sieved to $<2 \mathrm{~mm}$ particle size; a fraction of each sample was finely ground with an agate ball mill (Retsch PM400). To measure soil pH, $5 \mathrm{~g}$ of the sieved soils, were suspended in $12.5 \mathrm{~mL} \mathrm{MQ}$ water $(18.2 \mathrm{M} \Omega \mathrm{cm})$ and shaken end-over-end for $30 \mathrm{~min}$; $\mathrm{pH}$ was measured with a glass electrode allowing $5 \mathrm{~min}$ for equilibration. The organic carbon content of the soils was determined with a CN analyzer (Elementar VarioMax) after carbonates were removed with $50 \% \mathrm{HCl}$. Available phosphorus was extracted with $0.5 \mathrm{M}$ sodium bicarbonate $\left(\mathrm{NaHCO}_{3}\right)$ solution 
at pH 8.5 (Olsen et al., 1954) and assayed using a variation on the phosphomolybdate method (Drummond and Maher, 1995) by measuring absorbance in a $1 \mathrm{~cm}$ cell at $880 \mathrm{~nm}$ (CE 1011 spectrophotometer, Cecil Instruments). Amorphous (reactive) Fe, Al and Mn oxides were extracted from the finely ground soils by the citrate-bicarbonate-dithionite protocol developed by Kostka and Luther (1994); total Fe, Al and Mn concentrations in the filtered supernatants were assayed by ICP-MS. Total soil $\mathrm{Pb}(\mathrm{TPb})$ and total phosphorus $(\mathrm{P})$ content were assayed by ICP-MS following digestion of $0.2 \mathrm{~g}$ finely ground soil samples in an acid mixture composed of Primar Plus ${ }^{\mathrm{TM}}$ or Analytical grade HF (2.5 $\mathrm{mL} ; 40 \%), \mathrm{HNO}_{3}(2 \mathrm{~mL} ; 70 \%), \mathrm{HClO}_{4}(1 \mathrm{~mL} ; 70 \%)$ and $\mathrm{H}_{2} \mathrm{O}(2.5 \mathrm{~mL})$.

\subsection{Sequential Extraction of $\mathrm{Pb}$}

All soil samples were extracted, in duplicate, by a sequential extraction procedure (SEP) adapted from that of Li and Thornton (2001) which was originally developed by Tessier et al. (1979) as shown below.

1- Exchangeable fraction (F1): $1 \mathrm{~g}$ soil samples (<2mm sieved) were extracted in polycarbonate centrifuge tubes for $20 \mathrm{~min}$ with $8 \mathrm{~mL} 0.5 \mathrm{M} \mathrm{MgCl}_{2}$.

2- Bound to carbonate fraction (F2): the residues from F1 were extracted with $8 \mathrm{~mL} 1 \mathrm{M} \mathrm{CH}_{3} \mathrm{COONa}$ (adjusted to $\mathrm{pH} 5$ with $\mathrm{CH}_{3} \mathrm{COOH}$ ) for 5 hours.

3- Bound to iron and manganese oxides (F3): the residues from F2 were extracted with $10 \mathrm{~mL} 0.04$ $\mathrm{M}$ hydroxylamine hydrochloride in $25 \%(\mathrm{v} / \mathrm{v}) \mathrm{CH}_{3} \mathrm{COONa}$ at $96^{\circ} \mathrm{C}$ in a water bath for $6 \mathrm{~h}$ with occasional agitation.

4- Bound to organic matter (F4): the residues from $\mathrm{F} 3$ were extracted with $3 \mathrm{~mL} 0.02 \mathrm{M} \mathrm{HNO}_{3}$ and 5 $\mathrm{mL} 30 \% \mathrm{H}_{2} \mathrm{O}_{2}$ (adjusted to $\mathrm{pH} 2$ with $\mathrm{HNO}_{3}$ ) and tubes were heated to $85^{\circ} \mathrm{C}$ in a water bath and maintained for $2 \mathrm{~h}$ with occasional agitation. Three $\mathrm{mL} \mathrm{H}_{2} \mathrm{O}_{2}$ (adjusted to $\mathrm{pH} 2$ with $\mathrm{HNO}_{3}$ ) were then added and tubes were heated again for $3 \mathrm{~h}$ at $85^{\circ} \mathrm{C}$ with intermittent agitation. After cooling,

Sample tubes were centrifuged after each extraction step and the supernatant solutions were syringe filtered and retained for multi-element and $\mathrm{Pb}$ isotopic analysis by ICP-MS; the remaining soil was retained for the next extraction step. Carry-over from the previous step was accounted for gravimetrically.

The concentration of $\mathrm{Pb}\left(\mathrm{mg} \mathrm{kg}^{-1}\right)$ in the residual phase (F5) was calculated by subtracting the summation of $\mathrm{Pb}$ concentrations $\left(\mathrm{mg} \mathrm{kg}^{-1}\right)$ in the first four steps (F1-F4) from total soil $\mathrm{Pb}(\mathrm{TPb})$ 
measured in the $\mathrm{HF}-\mathrm{HClO}_{4}-\mathrm{HNO}_{3}$ acid soil digestates. For quality assurance, the recovery of the SEP procedure was tested on 11 samples in which the residual fraction was digested in a mixture of HF$\mathrm{HClO}_{4}-\mathrm{HNO}_{3}$ for $19 \mathrm{~h}$ (Atkinson et al., 2011); $95-110 \%$ recovery was achieved for $\mathrm{Pb}$.

The individual isotopic concentrations of $\mathrm{Pb}$ in the residual fraction (F5) were obtained from the isotopic abundances (IA) of the total soil $\mathrm{Pb}$ and fractions F1 to F4. (Eq. 1).

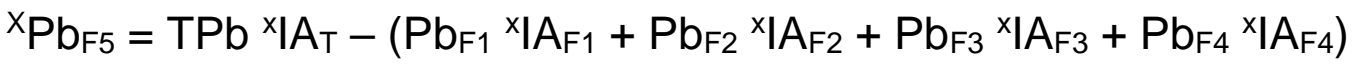

where, ${ }^{\times} \mathrm{Pb}_{F 5}$ is the concentration $\left(\mathrm{mol} \mathrm{kg}^{-1}\right)$ of a ${ }^{\times} \mathrm{Pb}$ isotope $\left({ }^{204} \mathrm{~Pb},{ }^{206} \mathrm{~Pb},{ }^{207} \mathrm{~Pb}\right.$ or $\left.{ }^{208} \mathrm{~Pb}\right)$ in the residual

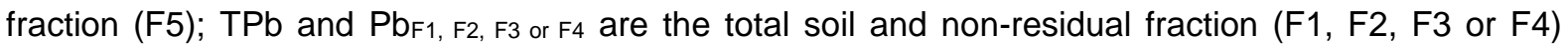
concentrations of $\mathrm{Pb}\left(\mathrm{mol} \mathrm{kg}^{-1}\right)$, respectively; ${ }^{\mathrm{x}} \mathrm{A}_{\mathrm{T}}$ and ${ }^{\mathrm{x}} \mathrm{A}_{\mathrm{F} 1}, \mathrm{~F} 2, \mathrm{F3}$ or $\mathrm{F}_{4}$ are the total soil and non-residual $(\mathrm{F} 1, \mathrm{~F} 2, \mathrm{~F} 3$ or $\mathrm{F} 4)$ isotopic abundances of $\times \mathrm{Pb}$.

No attempts were made to investigate artificial isotopic fractionation of $\mathrm{Pb}$ during the sequential extraction procedure. However, heavy atoms e.g. $\mathrm{Pb}$ isotopes with very small fractional differences in atomic mass would not support mass-dependent fractionation during chemical processes on any significant level (Bacon et al., 2006, Komárek et al., 2008, Lee and Yu, 2016, Monna et al., 1997). This was also found to be true for even much lighter elements e.g. Fe and $\mathrm{Cu}$ with relatively large fractional differences in atomic mass (Roebbert et al., 2018).

\subsection{Elemental and isotopic analyses by ICP-MS}

Concentrations of $\mathrm{Pb}, \mathrm{P}, \mathrm{Fe}, \mathrm{Al}$ and $\mathrm{Mn}$ in soil digestates and extracts were determined using ICP-MS (Model iCAPQ; Thermo Fisher Scientific GmbH, Bremen, Germany) as described in Shetaya et al. (2018). Briefly, samples and multi-element calibration standards (Certiprep/Fisher, UK) were diluted in $2 \%$ Primar Plus ${ }^{\mathrm{TM}}$ grade $\mathrm{HNO}_{3}$ and measured in triplicate. Internal standards, including $\mathrm{Rh}$ and Ir in $2 \% \mathrm{HNO}_{3}$ were introduced to the sample stream via a t-piece. Limits of detection (LOD) were calculated from analysis of 16 blanks. Montana soil reference material (NIST 2711) was used for quality assurance and $96 \pm 4 \%$ average recovery was achieved across all measured elements.

The ${ }^{204} \mathrm{~Pb},{ }^{206} \mathrm{~Pb},{ }^{207} \mathrm{~Pb}$ and ${ }^{208} \mathrm{~Pb}$ isotopic abundances in all samples were measured with a short dwell time of $2.5 \mathrm{~ms}$ and a total of 10,000 sweeps were used to mitigate the effects of 'plasma flicker' and achieve a high level of precision. For internal mass bias correction, a TI solution (10 $\left.\mu \mathrm{g} \mathrm{L}^{-1}\right)$, was introduced directly to the internal standard line and the variations in the ${ }^{203} \mathrm{TI} / 205 \mathrm{TI}$ ratios were used to 
correct shifts in $\mathrm{Pb}$ isotopic ratios (Blum and Bergquist, 2007, Shetaya et al., 2017). In addition, drift in mass bias was corrected externally by repeatedly assaying the certified Pb isotope standard NIST-981 and using linear interpolation to correct CPS ratios to isotopic ratios for samples (Atkinson et al., 2011, Marzouk et al., 2013b). To reduce polyatomic interferences from ${ }^{92} \mathrm{Os}-{ }^{16} \mathrm{O}$ (208 mass), ${ }^{193} \mathrm{Ir}-{ }^{-14} \mathrm{~N}(207$ mass) and ${ }^{205} \mathrm{TI}-\mathrm{H}$ (206 mass), the ICP-MS was used in the kinetic energy discrimination (KED) mode with helium as a collision gas. The isobaric interference to ${ }^{204} \mathrm{~Pb}$ from ${ }^{204} \mathrm{Hg}$ was corrected by determining intensity at $\mathrm{m} / \mathrm{z}=202\left({ }^{202} \mathrm{Hg}\right)$ and, from expected isotopic ratios, subtracting the intensity (CPS) attributed to ${ }^{204} \mathrm{Hg}$ within the instrument software. However, in practice the overall contribution of ${ }^{204} \mathrm{Hg}$ to the intensity at $\mathrm{m} / \mathrm{z} 204$ was trivial and the average ratio of ${ }^{204} \mathrm{Hg} / 204 \mathrm{~Pb}$ in the measured soil factions was estimated as $\mathbf{0 . 0 0 3 3}$. All solutions were diluted to ensure that the detector operated in 'pulse-counting' mode; data were rejected and sample analysis repeated, after appropriate dilution, if the detector 'tripped' to an analogue measurement in response to large count rates, typically $>1.5$ million counts $\mathrm{s}^{-1}$ for the ${ }^{208} \mathrm{~Pb}$ isotope (Marzouk et al., 2013a).

\subsection{Binary and ternary source apportionment}

Frequently, two identifiable sources of $\mathrm{Pb}$ are apparently present in soil, arising from (i) the petrol additive tetra-methyl $\mathrm{Pb}$ ('Petrol-Pb') and (ii) the underlying parent material ('Geogenic-Pb'). As a first approximation, we can then add a (single) third source, which is considered to originate from a range of industrial and power generation sources ('Industrial'). This may be similar to the Geogenic-Pb if there is a local source of coal or $\mathrm{Pb}$ ore.

The proportional contribution (\%) of any two $\mathrm{Pb}$ sources (e.g. Petrol, Geogenic or Industrial), to total soil $\mathrm{Pb}(\mathrm{TPb})$ or total $\mathrm{Pb}$ concentration in any of the SEP fractions, was calculated from Eq. 2 (Lee and Yu, 2016, Mao et al., 2014).

$$
\% \mathrm{~Pb}_{\mathrm{A}}=\frac{\mathrm{IR} \mathrm{R}_{\mathrm{T}}-\mathrm{IR} \mathrm{R}_{\mathrm{B}}}{\mathrm{IR}_{\mathrm{A}}-\mathrm{IR} \mathrm{R}_{\mathrm{B}}} \times 100
$$

where, $\% \mathrm{~Pb}_{\mathrm{A}}$ is the proportion of $\mathrm{TPb}$ from source $\mathrm{A}$; IR $\mathrm{R}$ and $\mathrm{IR} \mathrm{R}_{\mathrm{B}}$ are the $\mathrm{Pb}$ isotopic ratios ${ }^{206} \mathrm{~Pb} / 207 \mathrm{~Pb}$ or $\left.{ }^{208} \mathrm{~Pb} /{ }^{207} \mathrm{~Pb}\right)$ of sources $\mathrm{A}$ and $\mathrm{B}$, respectively; $\mathrm{IRT}$ is the measured $\mathrm{Pb}$ isotopic ratio $\left({ }^{206} \mathrm{~Pb} / 207 \mathrm{~Pb}\right.$ or ${ }^{208} \mathrm{~Pb} / 207 \mathrm{~Pb}$ ) of the whole soil or any individual SEP fraction (F1 - F5).

The relative contribution of three different end-member (pure) sources was modeled using Eq. 3 and Eq. 4 adapted from Cheng and $\mathrm{Hu}$ (2010) and Luo et al. (2015). 
237 where, \% $\mathrm{Pb}_{\mathrm{A}}, \% \mathrm{~Pb}$ a and \% $\mathrm{Pbc}$ are the proportions of $\mathrm{Pb}$ from sources $\mathrm{A}, \mathrm{B}$ and $\mathrm{C}$ to $\mathrm{TPb}$ or total $\mathrm{Pb}$ in any of the five SEP fractions. SEP fractions; ${ }^{x}\left|A_{A},{ }^{x}\right| A_{B}$ and ${ }^{x} \mid A_{C}$ are the isotopic abundances of the same isotope in the pure sources $A, B$ and $C$. The 'Solver' function in the software package Excel 2017 was used to minimize the residual standard deviation (RSD) between the modelled and measured isotopic abundances of all soils simultaneously. The operation was performed independently for total soil $\mathrm{Pb}(\mathrm{TPb})$ and for $\mathrm{Pb}$ in all of the five SEP fractions $(F 1-F 5)$. The anthropogenic- $\mathrm{Pb}$ isotopic distribution, in any soil phase (total or F1 - F5), was calculated by subtracting geogenic- $\mathrm{Pb}$ from total $\mathrm{Pb}(\mathrm{TPb})$ assuming uniform distribution of geogenic- $\mathrm{Pb}$ across the studied terrains (Eq. 5).

$$
{ }^{x} b_{A T}=P b_{T} \times A_{T}-P b_{G}{ }^{x} A_{G}
$$

251

252

where, $\times \mathrm{Pb}_{\mathrm{AT}}$ is the anthropogenic concentration $\left(\mathrm{mol} \mathrm{kg}^{-1}\right)$ of an isotope $\left({ }^{204} \mathrm{~Pb},{ }^{206} \mathrm{~Pb},{ }^{207} \mathrm{~Pb}\right.$ or $\left.{ }^{208} \mathrm{~Pb}\right)$, in any soil phase (total or $\mathrm{F} 1-\mathrm{F} 5$ ); $\mathrm{Pb}$ T and $\mathrm{Pb}_{\mathrm{G}}$ are the total soil $\mathrm{Pb}$ and geogenic- $\mathrm{Pb}$ concentrations ( $\mathrm{mol}$ $\mathrm{kg}^{-1}$ ), respectively (in the respective soil fraction); ${ }^{x} A_{T}$ and ${ }^{x} \mid A_{G}$ are the isotopic abundances in total and geogenic $\mathrm{Pb}$, respectively.

These approaches only present a simplified image of a complex geochemical system where soil $\mathrm{Pb}$ is a mixture of numerous sources. However, potentially they provide a means of quantifying the relative contribution of the two or three major $\mathrm{Pb}$ sources to each soil SEP fraction. 


\section{Results and Discussion}

262

263

264

265

266

267

268

269

270

271

272

273

274

275

276

277

278

279

280

281

\subsection{Soil Properties}

Key soil parameters are shown in Table 2. Total soil $\mathrm{Pb}$ concentrations (TPb) in the studied locations are discussed in detail by Shetaya et al. (2018). Briefly, TPb was greatest at the lead smelter site (SHI), peaking at $\sim 31,000 \mathrm{mg} \mathrm{kg}^{-1}$ with an average of $\sim 16,200 \mathrm{mg} \mathrm{kg}^{-1}$. This was followed by the industrial location CA-I (waste water treatment) and the urban locations CA-U and AX-U within Cairo and Alexandria with average TPb values of 171,160 , and $82.6 \mathrm{mg} \mathrm{kg}^{-1}$, respectively. However, significant difference ( $p<0.05 ; 2$ sample t-test; Minitab 17) were only found between CA-I and AX-U locations. All other non-background locations showed relatively low TPb levels with an average of $17 \mathrm{mg} \mathrm{kg}^{-1}$ which is slightly above the $\mathrm{Pb}$ average crustal abundance of $14 \mathrm{mg} \mathrm{kg}^{-1}$ (Emsley, 2011) indicating generally low levels of $\mathrm{Pb}$ contamination in the soils of Egypt. All soils, with the exception of a few individual samples, were alkaline and organic-poor ( $\mathrm{pH} 8$ and $1 \%$ SOC on average) likely due to the calcareous and sandy marine origins of Egyptian soils (Shaheen, 2009).

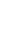

76


282 Table 2. Soil parameters including total soil $\mathrm{Pb}(\mathrm{TPb})$, soil $\mathrm{pH}$, organic content (\%SOC), available $\mathrm{P}$ (Olsen) and total $\mathrm{P}$, and reactive $\mathrm{Al}$, $\mathrm{Mn}$ and Fe 283 oxides; $n=$ number of samples in each location and $N A=$ not available (not measured). Letters I, $U, G$ and $B$ at the end of sample codes refer to 284 the industrial, urban, agriculture and background nature of the sampling location, respectively.

\begin{tabular}{|c|c|c|c|c|c|c|c|c|c|c|c|c|c|c|c|c|c|c|c|}
\hline \multirow[t]{2}{*}{ Location } & \multirow[t]{2}{*}{$\mathrm{n}$} & \multicolumn{2}{|c|}{$\begin{array}{l}\text { Total Pb (TPb) } \\
\left(m g k^{-1}\right)\end{array}$} & \multirow[b]{2}{*}{ Max. } & \multirow[b]{2}{*}{ Min. } & \multicolumn{2}{|l|}{$\mathrm{pH}$} & \multicolumn{2}{|l|}{$\begin{array}{c}\mathrm{SOC} \\
(\%)\end{array}$} & \multicolumn{2}{|c|}{$\begin{array}{l}\text { Available P } \\
\left(m g \mathrm{~kg}^{-1}\right)\end{array}$} & \multicolumn{2}{|c|}{$\begin{array}{l}\text { Total P } \\
\left(g \mathrm{~kg}^{-1}\right)\end{array}$} & \multicolumn{2}{|c|}{$\begin{array}{l}\mathrm{Al}_{2} \mathrm{O}_{3} \\
\left(g \mathrm{~kg}^{-1}\right)\end{array}$} & \multicolumn{2}{|c|}{$\begin{array}{l}\mathrm{MnO}_{2} \\
\left(g \mathrm{~kg}^{-1}\right)\end{array}$} & \multicolumn{2}{|c|}{$\begin{array}{l}\mathrm{Fe}_{2} \mathrm{O}_{3} \\
\left(g \mathrm{~kg}^{-1}\right)\end{array}$} \\
\hline & & Mean & SD & & & Mean & SD & Mean & SD & Mean & SD & Mean & SD & Mean & SD & Mean & SD & Mean & SD \\
\hline \multicolumn{20}{|c|}{ Industrial } \\
\hline HE-I & 4 & 19.5 & 2.83 & 23.5 & 16.9 & 9.7 & 1.3 & 0.95 & 0.19 & 27.9 & 7.47 & 0.24 & 0.06 & 1.08 & 0.77 & 0.02 & 0 & 3.21 & 1.01 \\
\hline $\mathrm{SH}-\mathrm{I}$ & 4 & 16201 & 15788 & 30808 & 2494 & 8 & 0.2 & 2.31 & 2.52 & 85.3 & 20.5 & 1.06 & 1.17 & 2.8 & 2.47 & 0.08 & 0.01 & 5.62 & 1.98 \\
\hline CA-I & 4 & 171 & 14.2 & 184 & 157 & 8.3 & 0 & 3.48 & 0.61 & 215 & 23.1 & 0.14 & 0.11 & 2.5 & 1.35 & 0.23 & 0.33 & 4.6 & 5.68 \\
\hline \multicolumn{20}{|l|}{ Urban } \\
\hline CA-U & 10 & 160 & 185 & 459 & 8.04 & 8.2 & 0.2 & 0.90 & 0.35 & 13.4 & 12.3 & 0.63 & 0.24 & 2.29 & 0.81 & 0.6 & 0.32 & 7.61 & 3.32 \\
\hline$A X-U$ & 5 & 82.6 & 94.6 & 247 & 18.3 & 7.8 & 0.7 & 3.20 & 1.92 & NA & NA & 0.4 & 0.05 & 30.5 & 8.68 & 0.59 & 0.12 & 30.3 & 9.84 \\
\hline SH-U & 8 & 25.4 & 10.3 & 37.6 & 11.9 & 7.8 & 0.2 & 0.96 & 0.79 & 39.6 & 43.1 & 1.13 & 0.46 & 2.53 & 0.18 & 0.6 & 0.08 & 13.1 & 4.92 \\
\hline IS-U & 8 & 18.7 & 11.1 & 40.5 & 6.47 & 7.9 & 0.2 & 0.52 & 0.50 & 13.2 & 10.7 & 0.28 & 0.15 & 1.31 & 0.32 & 0.09 & 0.05 & 2.67 & 0.79 \\
\hline AM-U & 4 & 10.3 & 2.56 & 12 & 5.81 & 8.5 & 0.5 & 0.11 & 0.06 & 1.8 & 0.34 & 0.33 & 0.05 & 1.15 & 0.5 & 0.01 & 0.02 & 2.26 & 0.62 \\
\hline All data & 35 & 68.5 & 119 & 459 & 5.81 & 8 & 0.4 & 1.33 & 1.49 & 18.6 & 25.5 & 0.57 & 0.39 & 9.09 & 13.3 & 0.44 & 0.3 & 12.9 & 12.1 \\
\hline \multicolumn{20}{|c|}{ Agriculture } \\
\hline IS-G & 4 & 6.66 & 0.26 & 6.97 & 6.35 & 8.5 & 0.2 & 0.15 & 0.07 & 5.14 & 6.83 & 0.27 & 0.17 & 0.73 & 0.17 & 0.03 & 0.01 & 1.09 & 0.72 \\
\hline SK-G & 4 & 11 & 0.73 & 11.6 & 10.2 & 7.8 & 0 & 0.29 & 0.04 & 9.24 & 5.95 & 0.59 & 0.04 & 2.03 & 0.03 & 0.21 & 0 & 3.51 & 0.05 \\
\hline All data & 8 & 8.78 & 2.31 & 11.6 & 6.35 & 8.1 & 0.4 & 0.22 & 0.09 & 7.19 & 5.74 & 0.43 & 0.21 & 1.38 & 0.76 & 0.12 & 0.11 & 2.30 & 1.46 \\
\hline \multicolumn{20}{|c|}{ Background } \\
\hline SI-B & 3 & 9.87 & 4.63 & 15.1 & 6.34 & 7.9 & 0.2 & 2.21 & 3.36 & NA & NA & 0.52 & 0.34 & 17.1 & 4.65 & 0.24 & 0.13 & 10.4 & 5.36 \\
\hline SZ-B & 8 & 3.37 & 1.60 & 5.84 & 1.90 & 7.8 & 0.1 & 0.05 & 0.04 & NA & NA & 1.19 & 1.39 & 1.5 & 0.43 & 0.03 & 0.05 & 1.31 & 0.44 \\
\hline All data & 11 & 4.96 & 3.21 & 15.1 & 1.90 & 8 & 0.2 & 1.07 & 1.53 & NA & NA & 0.68 & 0.75 & 15.5 & 12.8 & 0.15 & 0.11 & 7.38 & 5.38 \\
\hline
\end{tabular}




\subsection{Geochemical fractions of $\mathrm{Pb}$ determined by sequential extraction (SEP)}

289 The proportion (\%) of residual (non-reactive) $\mathrm{Pb}$ fraction (F5-Pb) was highest in the background sites 290 followed by agriculture, urban and industrial locations, respectively (Figure 1 and Table A.1); on average, $291 \mathrm{~F} 5-\mathrm{Pb}$ was inversely proportional to $\mathrm{TPb}\left(\mathrm{R}^{2}=0.97\right.$; power relationship) (Figure A.1). Since the residual 292 fraction (F5) represents $\mathrm{Pb}$ in primary and secondary minerals, e.g. galena (PbS) and pyromorphite $293\left(\mathrm{~Pb}_{5}\left(\mathrm{PO}_{4}\right)_{3} \mathrm{Cl}\right)$, that hold $\mathrm{Pb}$ within their crystal structure (Cotter-Howells and Thornton, 1991, Tessier et al., 294 1979), the exchange of $\mathrm{F} 5-\mathrm{Pb}$ with other soil phases is likely to be extremely slow and limited. This means 295 that any anthropogenic inputs of $\mathrm{Pb}$ will be almost exclusively distributed among the non-residual phases 296 (F1-F4) and that $\mathrm{F} 5-\mathrm{Pb}$ is mostly geogenic in origin. As the anthropogenic input of $\mathrm{Pb}$ increased (higher $297 \mathrm{TPb}), \mathrm{Pb}$ in F5-Pb proportionally decreased resulting in the inverse relationship between $\mathrm{TPb}$ and $\mathrm{F} 5-\mathrm{Pb}$. 298 This is also supported by the fact that F5-Pb was the largest fraction in the background, agriculture, urban 299 and cement factory locations (relatively low $\mathrm{TPb}$ ) as opposed to the lead smelter (SH-I) and waste water 300 treatment (CA-I) sites (highest $\mathrm{TPb}$ ) where the percentages of $\mathrm{F} 5-\mathrm{Pb}$ were only $10 \%$ and $25 \%$ of $\mathrm{TPb}$, on 301 average, respectively.

302 The second and third largest fractions in all soils, with the exception of SH-I and CA-I, were, respectively, 303 F3 (bound to metal oxides) and F4 (bound to organic). In alkaline soils, these two phases are likely to be 304 the most important non-residual phases for retention of heavy metals (Atkinson et al., 2011, Li and 305 Thornton, 2001, Tipping et al., 1986)

Location CA-I (waste water treatment) was dominated by F4-Pb (61\%) possibly due to its markedly elevated organic content (3.5\% SOC) in comparison to all other locations $(\mathrm{P}<<0.005$; paired t-test) (Table 1). The 308 largest fraction (44\%) in location SH-I (lead smelter) was F2 (bound to carbonates). Li and Thornton (2001) 309 also reported high F2-Pb levels $(24-55 \%)$ in mining and smelting sites with substantially elevated TPb 310 concentrations. Although, in mining locations, the high concentration of $\mathrm{F} 2-\mathrm{Pb}$ was attributed to the sheer 311 abundance of the thermodynamically favored cerussite $\left(\mathrm{PbCO}_{3}\right)$ (Brookins, 2012), the large $\mathrm{F} 2-\mathrm{Pb}$ fraction 312 in smelting sites may be due to the ability of $\mathrm{CH}_{3} \mathrm{COONa}$ to dissolve $\mathrm{PbO}$ (Clevenger et al., 1991) which is 313 a primary emission product of lead smelters (Foster and Lott, 1980). Moreover, Murphy (1992) found that $314 \mathrm{PbCO}_{3}$ is one of the major weathering products in the soils around old smelting facilities. 
The exchangeable fraction (F1) was only detectable in locations SH-I (1\%) and CA-U (0.3\%) (Figure 1 and Table A.1). In alkaline soils $\mathrm{Pb}$ ions are strongly adsorbed and exchangeable $\mathrm{Pb}(\mathrm{F} 1-\mathrm{Pb})$ is likely to be a very minor fraction (McBride, 1994, Sparks, 2003). However, when Pb levels are largely elevated, such as is location $\mathrm{SH}-\mathrm{I}$ (lead smelter), $\mathrm{Pb}$ ions will occupy progressively weaker sorption sites and so the proportion of exchangeable $\mathrm{Pb}$ increases (Degryse et al., 2009, Sastre et al., 2006, Tongtavee et al., 2005). In addition, $\mathrm{PbSO}_{4}$, which is an important component of $\mathrm{Pb}$ smelter emissions (Clevenger et al., 1991, Foster and Lott, 1980), may be initially incorporated into the exchangeable phase (F1) (Harrison et al., 1981).

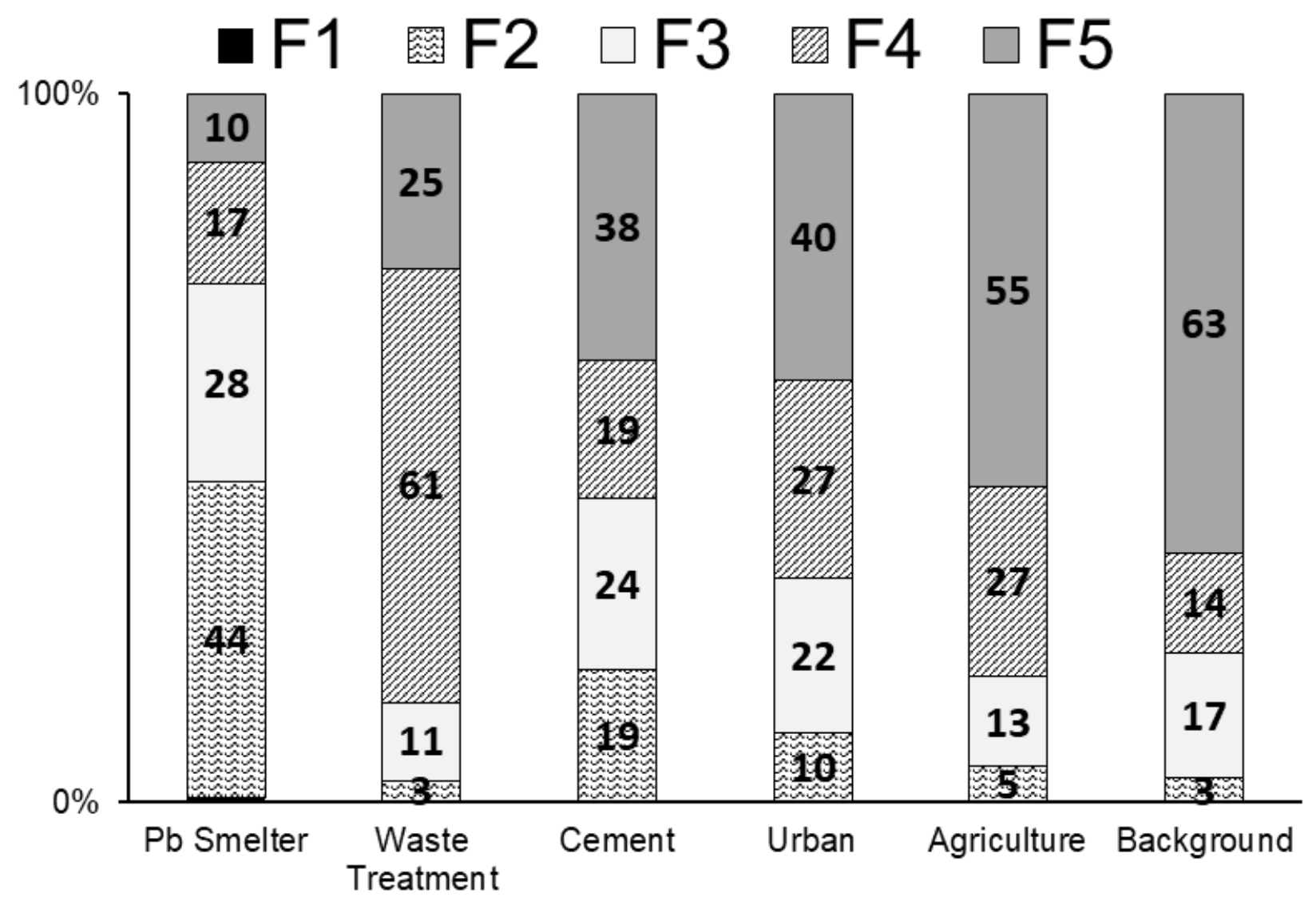

Figure 1. Proportion (\%) of $\mathrm{Pb}$ estimated in each of the five SEP fractions: $\mathrm{F} 1$ (exchangeable), $\mathrm{Fe}$ (bound to carbonates), F3 (bound to metal oxides), F4 (bound to organic matter) and F5 (residual). Industrial locations ( $\mathrm{Pb}$ smelter, waste water treatment, and cement factory) are displayed independently due to their different nature, agriculture and background sites are grouped together by site type. Numbers inside the boxes represent the proportion (\%) of each fraction to total soil $\mathrm{Pb}(\mathrm{TPb})$. Detailed data is displayed in Table A.1. 


\subsection{Isotopic fractionation of $\mathrm{Pb}$ in soil phases}

331 The isotopic ratios $(\mathrm{IR}){ }^{206} \mathrm{~Pb} /{ }^{207} \mathrm{~Pb}$ and ${ }^{208} \mathrm{~Pb} /{ }^{207} \mathrm{~Pb}$ measured or calculated in all SEP fractions (F1 - F5)

332 are shown in Table 3 for all sampling locations. Note that $\mathrm{F} 1-\mathrm{Pb}$ was below detection limit in most samples 333 and the calculation of F5-Pb IR (Eq. 1) produced reliable results only in soils where F5-Pb concentrations were $\geq 40 \%$ of $\mathrm{TPb}$ (c. $>50 \%$ of the samples) due to compounded errors in Eq. 1 where F5 was a minor constituent of TPb. Shetaya et al. (2018) reported that petrol- $\mathrm{Pb}$ (IR of $1.11 \pm 0.002$ for ${ }^{206} \mathrm{~Pb} /{ }^{207} \mathrm{~Pb}$ and $2.385 \pm 0.002$ for ${ }^{208} \mathrm{~Pb} /{ }^{207} \mathrm{~Pb}$ ) and geogenic- $\mathrm{Pb}$ (IR values of $1.212 \pm 0.004$ for ${ }^{206} \mathrm{~Pb} / 207 \mathrm{~Pb}$ and $2.482 \pm$ 0.006 for ${ }^{208} \mathrm{~Pb} /{ }^{207} \mathrm{~Pb}$ ) are likely to be the two major sources of $\mathrm{Pb}$ in the soils of Egypt. Figure 2 clearly shows that the IRs ${ }^{206} \mathrm{~Pb} /{ }^{207} \mathrm{~Pb}$ and ${ }^{208} \mathrm{~Pb} /{ }^{207} \mathrm{~Pb}$ for all soils in all five SEP fractions are aligned closely to a binary mixing line between the isotopic signatures of the two end members (nominally 'petrol' and 'geogenic'). This suggests that these are the two major contributors to both non-residual and residual $\mathrm{Pb}$ fractions in the studied soils with only minor contributions from other potential sources contributing to scattering of the data around the binary line. This agrees with the findings of other studies that adopted the binary plot approach to resolve the likely major sources of $\mathrm{Pb}$ using the isotopic signatures of two 'pure' end members. For example, Monna et al. (1997) found that the $\mathrm{Pb}$ isotopic signatures of various environmental samples from UK and France were aligned around a mixing line between geogenic- $\mathrm{Pb}$ $\left({ }^{206} \mathrm{~Pb} / 207 \mathrm{~Pb} \approx 1.17-1.19\right)$ and petrol- $\mathrm{Pb}\left({ }^{206} \mathrm{~Pb} / 207 \mathrm{~Pb} \approx 1.05-1.08\right)$. Chenery et al. (2012), Izquierdo et al. (2012) and Mao et al. (2014) also found that the Pb isotopic signatures of their investigated UK samples (soils, plants and aerosols) indicated an almost exclusive mixing between petrol- $\mathrm{Pb}\left({ }^{206} \mathrm{~Pb} /{ }^{207} \mathrm{~Pb} \approx 1.06-\right.$ 1.09) and $\mathrm{Pb}$ from indigenously mined coal $\left({ }^{206} \mathrm{~Pb} / 207 \mathrm{~Pb} \approx 1.16-1.21\right)$. This seems to be a universal pattern at least in the European environments where the $\mathrm{Pb}$ signatures of environmental samples align around a binary line between geogenic- $\mathrm{Pb}\left({ }^{206} \mathrm{~Pb} /{ }^{207} \mathrm{~Pb} \approx 1.22-1.24\right)$ and petrol- $\mathrm{Pb}\left({ }^{206} \mathrm{~Pb} /{ }^{207} \mathrm{~Pb} \approx 1.12-1.14\right)$

352 (Komárek et al., 2008).

To investigate the isotopic distribution of $\mathrm{Pb}$ in relation to their SEP phase, the ${ }^{206} \mathrm{~Pb} /{ }^{207} \mathrm{~Pb} \mathrm{IR}$ of all soils were plotted against total soil $\mathrm{Pb}(\mathrm{TPb})$ (Figure 3). In all five SEP fractions (F1- F5), Pb isotopic signatures formed discrete clusters according to their origins. Soils from the background location (SZ-B) were grouped cement factory locations were distributed between geogenic- $\mathrm{Pb}$ and petrol- $\mathrm{Pb}$ indicating broadly similar 
contributions from both sources. Waste treatment locations and urban soils with $\mathrm{TPb}>100 \mathrm{mg} \mathrm{kg}^{-1}$ were more inclined toward the petrol-Pb isotopic signature. In all soil fractions, locations with higher values of $\mathrm{TPb}$ were inclined toward the petrol signature of ${ }^{206} \mathrm{~Pb} / 207 \mathrm{~Pb}$.

Lead smelter (SH-I) soils also formed clusters with ${ }^{206} \mathrm{~Pb} /{ }^{207} \mathrm{~Pb} \mathrm{IRs}$ that fell between those of geogenic- $\mathrm{Pb}$ and petrol- $\mathrm{Pb}$ in all four non-residual $\mathrm{Pb}$ fractions (Figure $3 \mathrm{~A}-\mathrm{D}$ ); however, given the much greater $\mathrm{Pb}$ concentrations in these soils, it is likely that the smelter would generate a unique ${ }^{206} \mathrm{~Pb} / 207 \mathrm{~Pb}$ signature and the contribution of geogenic- $\mathrm{Pb}$ and petrol- $\mathrm{Pb}$ at this location was probably trivial in comparison. This is supported by the fact that the $\mathrm{Pb}$ smelting facility that was located in this site was recycling scrap lead from various industries and sources e.g. old batteries, and most of this recycled $\mathrm{Pb}$ was originally imported rather than indigenously mined (Labib et al., 2003, Safar et al., 2014). The measured ${ }^{206} \mathrm{~Pb} /{ }^{207} \mathrm{~Pb}$ ratios $(1.151-$ $1.155)$ in $\mathrm{SH}-\mathrm{I}$ site, in all non-residual phases, agreed well with the average 'industrial' ${ }^{206} \mathrm{~Pb} / 207 \mathrm{~Pb}$ ratios (1.147 - 1.160) reported by Monna et al. (1997).

Most samples showed almost identical patterns across the non-residual (F2, F3 and F4) phases (Figure 3 B - D). Bacon et al. (2006) and Lee and Yu (2016) also reported homogenous distributions of Pb IRs among non-residual soil phases in spite of distinct $\mathrm{Pb}$ isotopic signatures between $\mathrm{Pb}$ sources, soil depths and sampling locations. In our work, the apparent consistency of $\mathrm{Pb}$ isotopic signatures among non-residual phases is also statistically supported (paired t-test; Minitab 17) by insignificant differences between ${ }^{206} \mathrm{~Pb} /{ }^{207} \mathrm{~Pb}$ or ${ }^{208} \mathrm{~Pb} /{ }^{207} \mathrm{~Pb}$ ratios of the non-residual fractions, with the single exception of ${ }^{206} \mathrm{~Pb} / 207 \mathrm{~Pb}$ when comparing F3 and F4 (Table A.2). Comparison with $\mathrm{F} 1-\mathrm{Pb}$ and $\mathrm{F} 5-\mathrm{Pb}$ isotopic signatures could not be discussed with confidence due to the limited number of valid results; however, the few available data points (Figure $3 \mathrm{~A}$ and $\mathrm{E}$ ) appear to resemble those of F2, F3 and F4 (Figure $3 \mathrm{~B}-\mathrm{D}$ ).

The similarity of isotopic signatures across the fractions (F1 - F5) may indicate that $\mathrm{Pb}$ from anthropogenic sources (petrol and other) may have no preferential affinity for specific non-residual or residual soil phases and has been sufficiently labile to be assimilated into common pools with geogenic- $\mathrm{Pb}$ due to prolonged contact with the soil. However, isotopic homogeneity between fractions should be interpreted carefully because differences in the $\mathrm{Pb}$ isotopic abundances between SEP fractions may only be measurable if a given $\mathrm{Pb}$ source, with a distinct isotopic signature, had a high chemical affinity for specific soil phases 
385 resulting in limited mixing between fractions. This would depend on both the $\mathrm{Pb}$ source speciation and the 386 soil chemical properties. Our collection of soils fell within a relatively narrow range of properties (Table 2)

387 thus potentially contributing to the apparent $\mathrm{Pb}$ isotopic homogeneity between the non-residual (and 388 possibly residual) fractions. Furthermore, sequential extraction procedures are prone to re-adsorption 389 effects which may have contributed to the similarity in the $\mathrm{Pb}$ isotopic patterns between the non-residual 390 fractions. Mass-dependent fractionation of $\mathrm{Pb}$ between different soil phases is likely to be very small due 391 to the high mass of the $\mathrm{Pb}$ isotopes and would not be detectable by a quadrupole ICP. 
393 Table 3. Isotopic ratios $\left({ }^{206} \mathrm{~Pb} / 207 \mathrm{~Pb}\right.$ and $\left.{ }^{208} \mathrm{~Pb} /{ }^{207} \mathrm{~Pb}\right)$ measured in the four SEP fractions: $\mathrm{F} 1=$ exchangeable, $\mathrm{F} 2=$ bound to carbonates, $\mathrm{F} 3=$ bound

394 to Fe/Mn reactive oxides, F4=bound to organic matter, F5=Resdiual. $n=$ number of samples in each location, $S D=$ standard deviation between soils 395 sampled form the same site, $\mathrm{ND}=$ not detectable (below detection limit), $\mathrm{NM}=$ not measured and $\mathrm{NA}=$ not applicable.

\begin{tabular}{|c|c|c|c|c|c|c|c|c|c|c|c|c|c|c|c|c|c|c|c|c|c|}
\hline \multirow{3}{*}{$\begin{array}{l}\text { Sampling } \\
\text { Locations }\end{array}$} & \multirow[t]{3}{*}{$\mathrm{n}$} & \multirow{2}{*}{\multicolumn{2}{|c|}{$\begin{array}{l}\mathrm{F} 1 \\
{ }^{206} \mathrm{~Pb} /{ }^{207} \mathrm{~Pb}\end{array}$}} & \multirow{2}{*}{\multicolumn{2}{|c|}{${ }^{208} \mathrm{~Pb} /{ }^{207} \mathrm{~Pb}$}} & \multirow{2}{*}{\multicolumn{2}{|c|}{$\begin{array}{l}\mathrm{F} 2 \\
{ }^{206} \mathrm{~Pb} /{ }^{207} \mathrm{~Pb}\end{array}$}} & \multirow{2}{*}{\multicolumn{2}{|c|}{${ }^{208} \mathrm{~Pb} /{ }^{207} \mathrm{~Pb}$}} & \multirow{2}{*}{\multicolumn{2}{|c|}{$\begin{array}{l}\mathrm{F} 3 \\
{ }^{206} \mathrm{~Pb} /{ }^{207} \mathrm{~Pb}\end{array}$}} & \multirow{2}{*}{\multicolumn{2}{|c|}{${ }^{208} \mathrm{~Pb} /{ }^{207} \mathrm{~Pb}$}} & \multirow{2}{*}{\multicolumn{2}{|c|}{$\begin{array}{l}\mathrm{F} 4 \\
{ }^{206} \mathrm{~Pb} /{ }^{207} \mathrm{~Pb}\end{array}$}} & \multirow{2}{*}{\multicolumn{2}{|c|}{${ }^{208} \mathrm{~Pb} /{ }^{207} \mathrm{~Pb}$}} & \multirow{2}{*}{\multicolumn{2}{|c|}{$\begin{array}{l}\mathrm{F} 5 \\
{ }^{206} \mathrm{~Pb} /{ }^{207} \mathrm{~Pb}\end{array}$}} & \multirow{2}{*}{\multicolumn{2}{|c|}{${ }^{208} \mathrm{~Pb} /{ }^{207} \mathrm{~Pb}$}} \\
\hline & & & & & & & & & & & & & & & & & & & & & \\
\hline & & Mean & SD & Mean & SD & Mean & SD & Mean & SD & Mean & SD & Mean & SD & Mean & SD & Mean & SD & Mean & SD & Mean & SD \\
\hline \multicolumn{22}{|l|}{ Industrial } \\
\hline HE-I & 4 & ND & NA & ND & NA & 1.159 & 0.011 & 2.441 & 0.008 & 1.161 & 0.012 & 2.437 & 0.013 & 1.161 & 0.014 & 2.437 & 0.014 & 1.149 & 0.013 & 2.431 & 0.011 \\
\hline SH-I & 4 & 1.151 & 0.008 & 2.425 & 0.009 & 1.155 & 0.016 & 2.435 & 0.013 & 1.152 & 0.006 & 2.421 & 0.007 & 1.151 & 0.005 & 2.433 & 0.006 & NA & NA & NA & NA \\
\hline CA-I & 4 & ND & NA & ND & NA & 1.141 & 0.001 & 2.419 & 0.002 & 1.144 & 0.002 & 2.425 & 0.002 & 1.139 & 0.001 & 2.420 & 0.007 & NA & NA & NA & NA \\
\hline \multicolumn{22}{|l|}{ Urban } \\
\hline $\mathrm{CA}-\mathrm{U}$ & 10 & 1.148 & 0.008 & 2.424 & 0.020 & 1.169 & 0.023 & 2.453 & 0.029 & 1.167 & 0.021 & 2.444 & 0.022 & 1.164 & 0.021 & 2.443 & 0.021 & 1.183 & 0.017 & 2.457 & 0.014 \\
\hline$A X-U$ & 5 & NM & NA & NM & NA & NM & NA & NM & NA & NM & NA & NM & NA & NM & NA & NM & NA & NM & NA & NM & NA \\
\hline $\mathrm{SH}-\mathrm{U}$ & 8 & ND & NA & ND & NA & 1.161 & 0.004 & 2.437 & 0.006 & 1.166 & 0.006 & 2.444 & 0.008 & 1.163 & 0.011 & 2.443 & 0.009 & 1.257 & 0.143 & 2.822 & 0.430 \\
\hline IS-U & 8 & ND & NA & ND & NA & 1.156 & 0.007 & 2.433 & 0.006 & 1.156 & 0.006 & 2.435 & 0.009 & 1.158 & 0.005 & 2.437 & 0.010 & 1.169 & 0.017 & 2.460 & 0.019 \\
\hline AM-U & 4 & ND & NA & ND & NA & 1.199 & 0.014 & 2.474 & 0.013 & 1.202 & 0.015 & 2.483 & 0.011 & 1.190 & 0.019 & 2.467 & 0.020 & 1.165 & 0.021 & 2.450 & 0.017 \\
\hline All data & 35 & NA & NA & NA & NA & 1.167 & 0.019 & 2.446 & 0.022 & 1.168 & 0.019 & 2.447 & 0.020 & 1.166 & 0.018 & 2.445 & 0.017 & 1.186 & 0.051 & 2.506 & 0.173 \\
\hline \multicolumn{22}{|c|}{ Agriculture } \\
\hline IS-G & 4 & ND & NA & ND & NA & 1.172 & 0.013 & 2.448 & 0.028 & 1.172 & 0.010 & 2.451 & 0.010 & 1.172 & 0.016 & 2.457 & 0.021 & 1.162 & 0.013 & 2.445 & 0.013 \\
\hline SK-G & 4 & ND & NA & ND & NA & 1.174 & 0.011 & 2.453 & 0.009 & 1.176 & 0.005 & 2.455 & 0.006 & 1.176 & 0.004 & 2.453 & 0.007 & 1.181 & 0.001 & 2.466 & 0.011 \\
\hline All data & 8 & ND & NA & ND & NA & 1.173 & 0.011 & 2.450 & 0.020 & 1.174 & 0.007 & 2.453 & 0.008 & 1.174 & 0.011 & 2.455 & 0.015 & 1.168 & 0.014 & 2.452 & 0.016 \\
\hline \multicolumn{22}{|c|}{ Background } \\
\hline SI-B & 3 & NM & NA & NM & NA & NM & NA & NM & NA & NM & NA & NM & NA & NM & NA & NM & NA & NM & NA & NM & NA \\
\hline SZ-B & 8 & ND & NA & ND & NA & 1.203 & 0.006 & 2.486 & 0.011 & 1.200 & 0.005 & 2.477 & 0.004 & 1.192 & 0.019 & 2.462 & 0.025 & 1.196 & 0.019 & 2.461 & 0.012 \\
\hline All data & 11 & NA & NA & NA & NA & 1.203 & 0.006 & 2.486 & 0.011 & 1.200 & 0.005 & 2.477 & 0.004 & 1.192 & 0.019 & 2.462 & 0.025 & 1.196 & 0.019 & 2.461 & 0.012 \\
\hline
\end{tabular}

396

397

398 


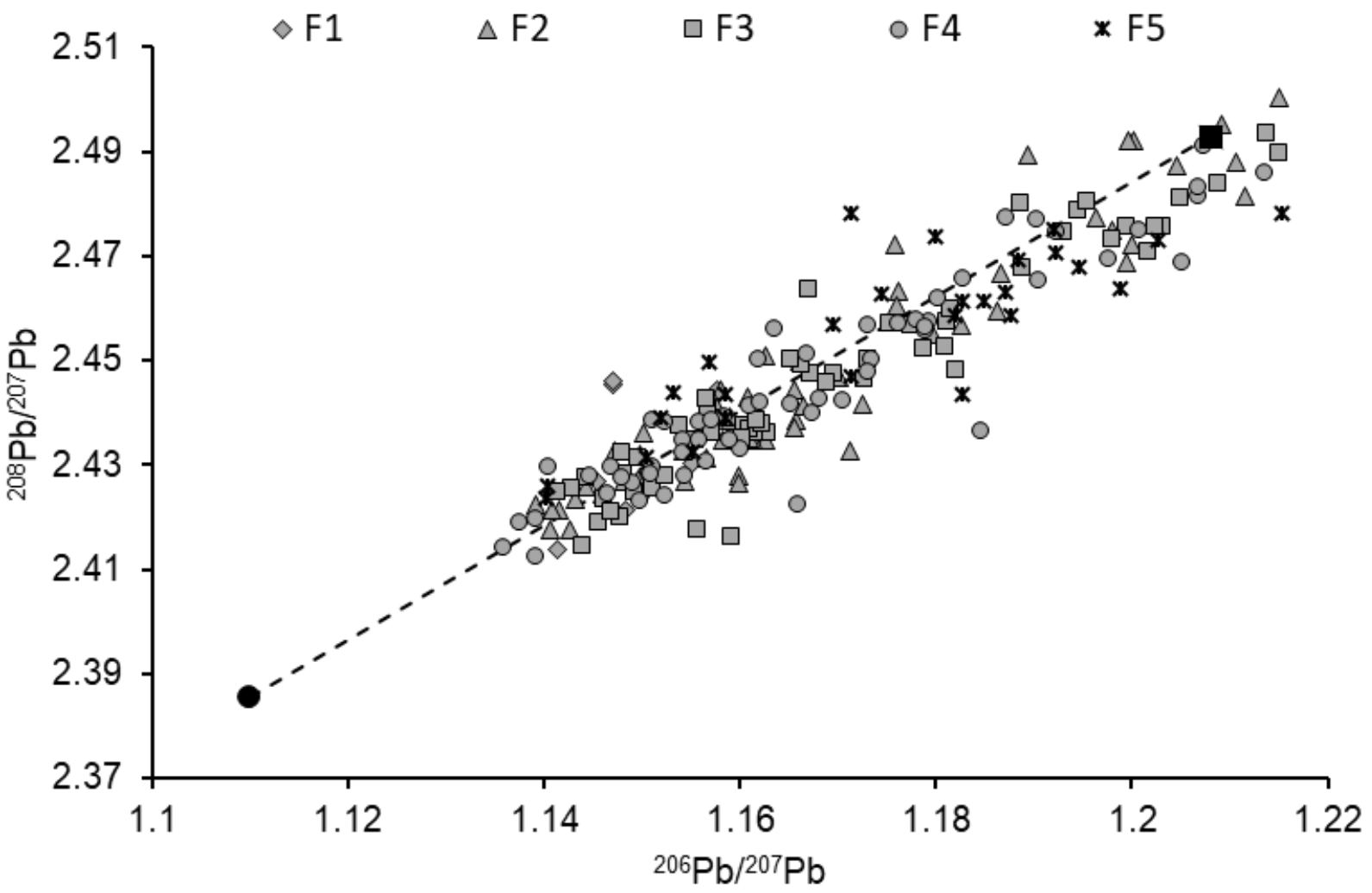

400

401

402

403

404

405

406

407

408

409

410

411

412

413

414

415

416

\section{5}

07

.

Figure 2. Isotopic ratios $\left({ }^{206} \mathrm{~Pb} /{ }^{207} \mathrm{~Pb}\right.$ vs $\left.{ }^{208} \mathrm{~Pb} / 207 \mathrm{~Pb}\right)$ of the $\mathrm{F} 1, \mathrm{~F} 2, \mathrm{~F} 3, \mathrm{~F} 4$ and $\mathrm{F} 5 \mathrm{SEP}$ fractions in all soil samples. Petrol- $\mathrm{Pb}$ (black circle) and geogenic- $\mathrm{Pb}$ (black square) signatures are also shown as two possible end members; the dashed line is the mixing line between them. F5 fraction signatures are shown for samples where F5-Pb was $\geq 40 \%$ of total soil $\mathrm{Pb}$ (TPb).

408

11

12

14

15



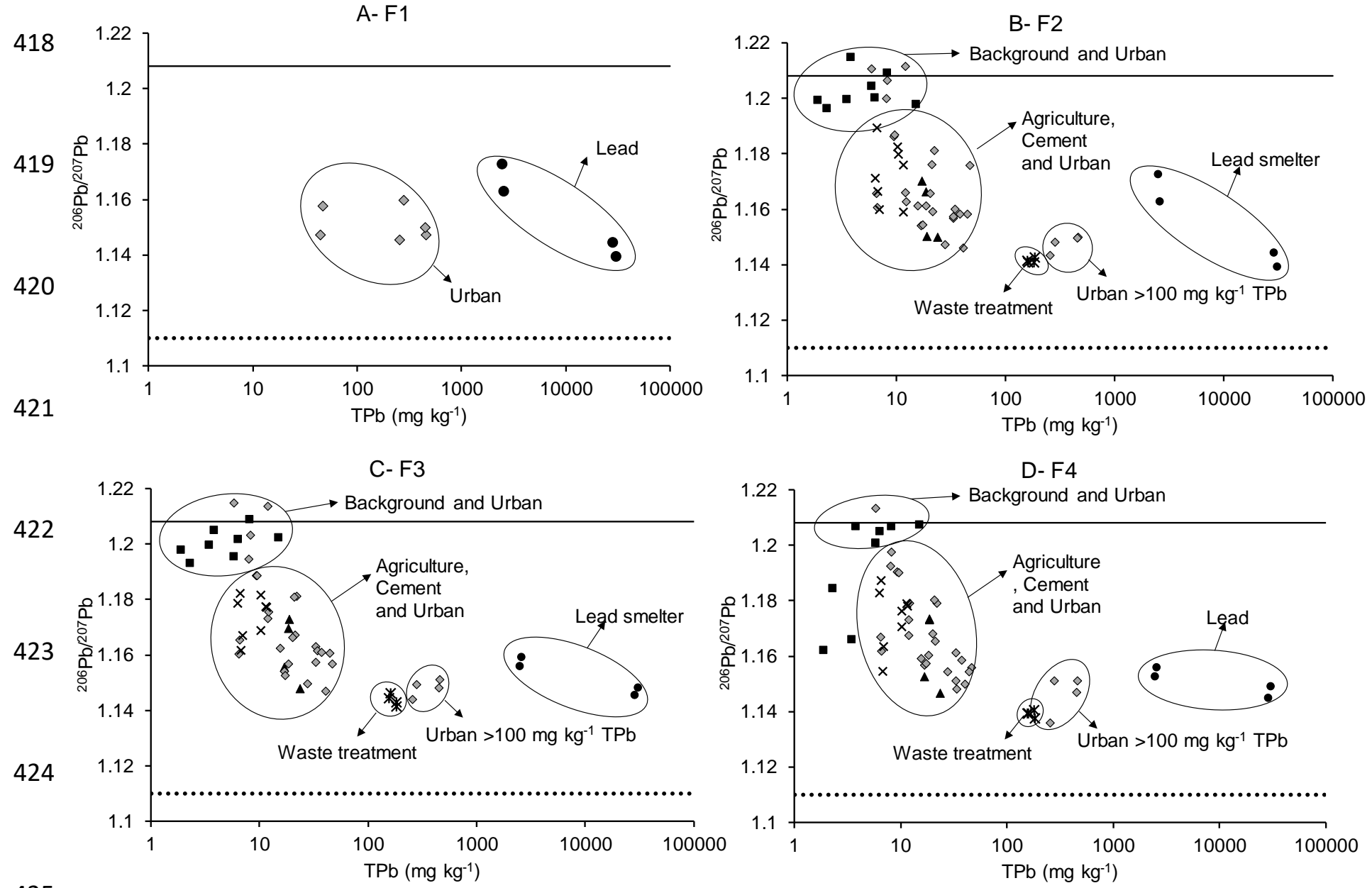

425

426

C- F3

E- F5

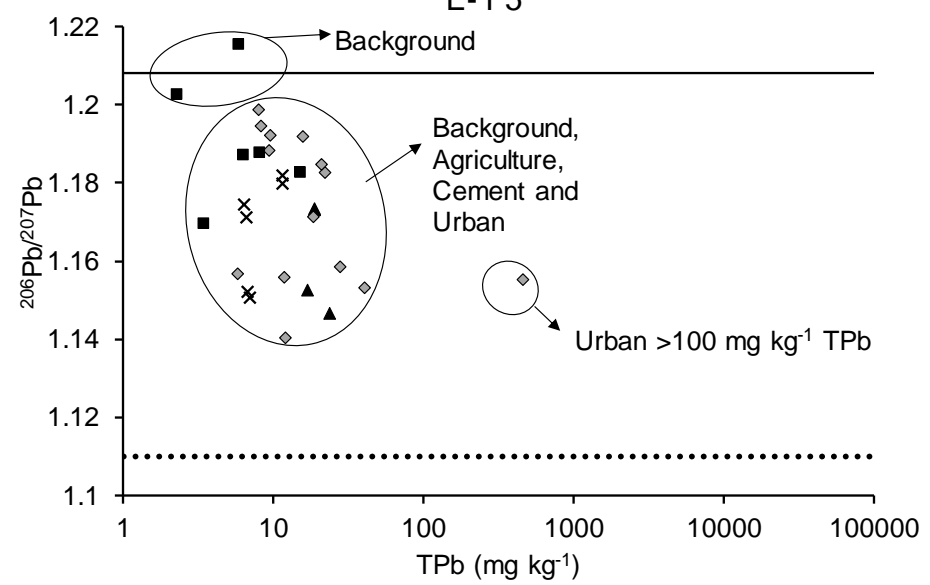

Figure 3. Isotopic ratios ${ }^{206} \mathrm{~Pb} /{ }^{207} \mathrm{~Pb}$ vs total soil $\mathrm{Pb}\left(\mathrm{TPb}\right.$; $\left.\mathrm{mg} \mathrm{kg}^{-1}\right)$ for all SEP fractions: $\mathrm{F} 1(\mathrm{~A})$, F2 (B), F3 (C), F4 (D) and F5 (E). Sampling locations included lead smelter (black circles), waste water treatment (asterisks), urban (grey diamonds), agriculture (crosses), cement factory (black triangles) and background (black squares). Solid and dotted lines represent the ${ }^{206} \mathrm{~Pb} / 207 \mathrm{~Pb}$ ratios of geogenic- $\mathrm{Pb}$ and petrol- $\mathrm{Pb}$, respectively. 


\section{3.4. Relative contribution of geogenic and petrol $\mathrm{Pb}$ pools}

439 The proportional contributions (\%) of petrol- $\mathrm{Pb}$ and geogenic- $\mathrm{Pb}$ in non-residual fractions $\mathrm{F} 2$, F3 and F4 in 440 all soils, except SH-I (lead smelter) soils, were estimated from Eq. 2. Figure 4 shows that the greatest 441 proportion of petrol-Pb was found in the industrial location CA-I (wastewater treatment) with 66, 68 and $44270 \%$ of $\mathrm{Pb}$ in fractions F3, F2 and F4, respectively. This was followed by the cement factory (HE-I) and 443 urban locations where there were almost equal proportions of petrol- $\mathrm{Pb}$ and geogenic- $\mathrm{Pb}$. Agricultural 444 locations were characterized by low petrol- $\mathrm{Pb}$ contributions $(34-36 \%)$ to all fractions while background 445 locations were dominated (84 - 91\%) by geogenic- $\mathrm{Pb}$. Overall, higher total soil $\mathrm{Pb}(\mathrm{TPb})$ concentrations 446 resulted in a greater proportion of petrol- $\mathrm{Pb}$ in all fractions.

447 It appears from Figure 4 that the proportion of Petrol-Pb was consistent within all fractions. As mentioned 448 previously (section 3.3), measurable differences in the distribution of anthropogenic- $\mathrm{Pb}$ between soil 449 phases would require a high affinity of the emitted $\mathrm{Pb}$ for one particular phase and very slow mixing between

450 fractions. However, the evidence from this study suggests that the different sources of $\mathrm{Pb}$ have effectively 451 mixed between (SEP) fractions. 
A- Cement

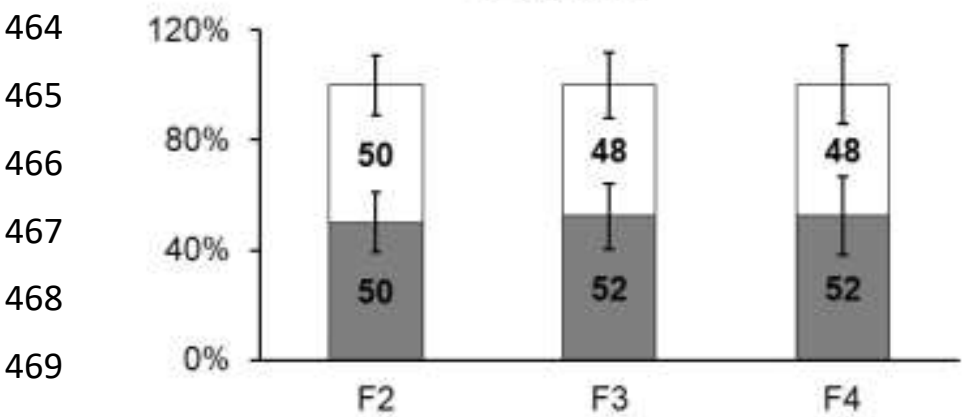

470

471

472
473
474
475
476

477

478

479

480

481

482

483

484

485

486

487

488

489

490

491

492

493

494
B- Waste Treatment

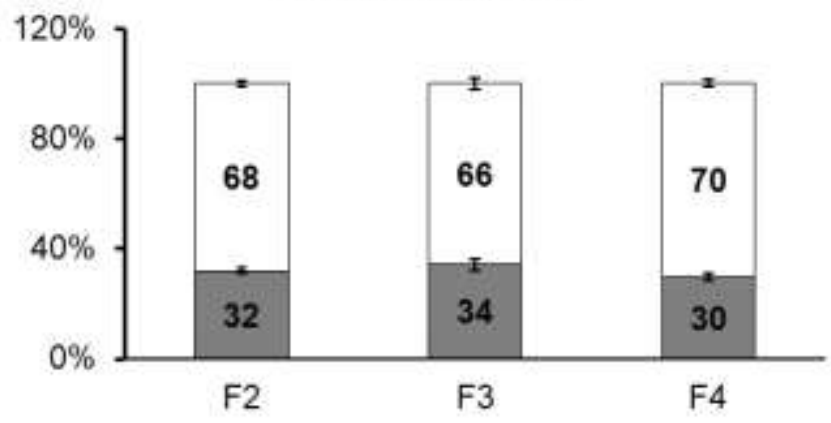

D- Agriculture

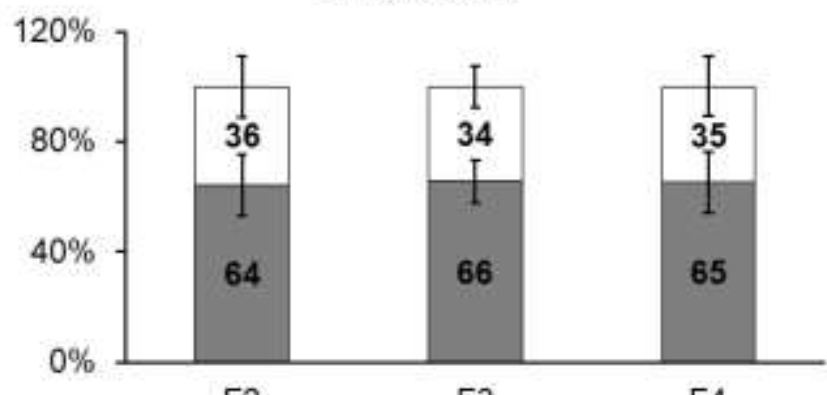

F2

F3

E-Background

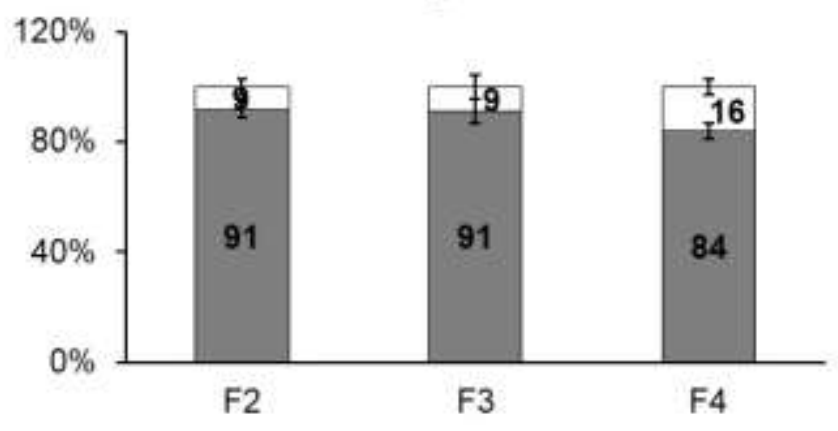

Figure 4. Proportion (\%) of petrol- $\mathrm{Pb}$ (white boxes) and geogenic- $\mathrm{Pb}$ (dark grey boxes) in the non-residual fractions F2, F3 and F4 in all sampling locations, excluding the SH-I (lead smelter) samples. Numbers inside the boxes represent the proportion (\%) of each fraction relative to total $\mathrm{Pb}$ in the respective soil phase. Error bars represent the standard deviation between soils from the same location. 


\subsection{Interpreting $\mathrm{Pb}$ isotopic signatures assuming three sources}

We investigated the possibility of modelling the contribution of a third 'industrial' $\mathrm{Pb}$ contribution to the total $\mathrm{Pb}$ pool in addition to the geogenic- $\mathrm{Pb}$ and petrol- $\mathrm{Pb}$ end-members in all soil phases. As discussed previously (section 3.3), soils from the Lead Smelter location (SH-I) are likely to have a distinct isotopic signature (IR of 1.14 for ${ }^{206} \mathrm{~Pb} /{ }^{207} \mathrm{~Pb}$ and 2.41 for ${ }^{208} \mathrm{~Pb} /{ }^{207} \mathrm{~Pb}$ for total soil $\mathrm{Pb}$ ) that is independent in origin from the other two definable sources (petrol- $\mathrm{Pb}$ and geogenic- $\mathrm{Pb}$ ). This smelting facility recycled lead from various industries that used imported $\mathrm{Pb}$ metal, so it seemed possible that the $\mathrm{Pb}$ signature of the $\mathrm{SH}-\mathrm{I}$ location soil may represent the range of $\mathrm{Pb}$ used industrially in Egypt. As such, the smelter site could be considered as representing a third $\mathrm{Pb}$ isotope end-member.

However, the IA values of ${ }^{208} \mathrm{~Pb}$ in the smelter samples were too low to represent a discrete end member. To resolve a hypothetical third $\mathrm{Pb}$ source (designated 'industrial $\mathrm{Pb}$ '), it was necessary to lower the isotopic abundances $(\mathrm{IA})$ of ${ }^{204} \mathrm{~Pb},{ }^{206} \mathrm{~Pb},{ }^{207} \mathrm{~Pb}$ using a factor of 0.985 , allowing the ${ }^{208} \mathrm{~Pb} \mathrm{IA}$ to compensate by keeping the sum of IA values equal to 1. The 'Solver' function of Excel together with Eq. 3 and Eq. 4 (as described in section 2.5) was then employed to find an optimum 'industrial' end-member for TPb and the SEP fractions across all soils simultaneously. The best fit between modelled and measured isotopic abundances of ${ }^{206} \mathrm{~Pb},{ }^{207} \mathrm{~Pb}$ and ${ }^{208} \mathrm{~Pb}$ was achieved with IR values of 1.14 for ${ }^{206} \mathrm{~Pb} /{ }^{207} \mathrm{~Pb}$ and 2.48 for ${ }^{208} \mathrm{~Pb} /{ }^{207} \mathrm{~Pb}$ in the 'industrial' source (Figure A.2). The resulting contributions of all three hypothetical $\mathrm{Pb}$ sources (petrol, geogenic and industrial) are shown in Figure 5. The industrial-Pb source contribution was relatively uniform across all soils and soils fractions ranging from $13-28 \%$ of $\mathrm{TPb}$. The relative contribution of petrol- $\mathrm{Pb}$ and geogenic $\mathrm{Pb}$ displayed similar patterns to that observed with the binary model (section 3.5; Figure 4) showing considerably higher geogenic- $\mathrm{Pb}$ contributions in the background and agriculture soils (Figure $5 \mathrm{D}$ and $\mathrm{E}$ ), almost equal contribution of both sources in the cement factory location (Figure $5 \mathrm{~A}$ ) and a larger contribution from petrol- $\mathrm{Pb}$ in the waste treatment location.

In an alternative approach, the anthropogenic- $\mathrm{Pb}$ isotopic abundances were calculated by subtracting an estimate of the geogenic- $\mathrm{Pb}$ contribution from total $\mathrm{Pb}$ in all soil fractions (Eq. 5). Geogenic $\mathrm{Pb}$ isotope concentrations were estimated from the average $\mathrm{Pb}$ concentration and isotopic abundances of the background location SZ-B. This approach assumes a uniform distribution of geogenic-Pb in the studied 
522 soils arising from similar underlying geological $\mathrm{Pb}$ concentrations and isotopic signatures across all the 523 studied terrains. The molar concentrations of all four (anthropogenic) $\mathrm{Pb}$ isotopes were then calculated

524 from Eq. 5. Figure 6 shows the isotopic signatures of the calculated anthropogenic- $\mathrm{Pb}$ in all soil fractions.

525 However, it was apparent that the 'removal' of such a small background Pb content produced little change

526 in the distribution of $\mathrm{Pb}$ isotopes and the 'anthropogenic' isotopic ratios of $\mathrm{Pb}$ were distributed between

527 petrol- $\mathrm{Pb}$ and geogenic- $\mathrm{Pb}$ and well beyond the $\mathrm{Pb}$ smelter data (higher ${ }^{206} \mathrm{~Pb} /{ }^{207} \mathrm{~Pb}$ ratios) provisionally

528 assumed to represent the 'industrial $\mathrm{Pb}$ ' signature. The smelter $\mathrm{Pb}$ is certainly a candidate source for the

529 mix of $\mathrm{Pb}$ in Egyptian soils - and this is consistent with the fact that it falls on the periphery of the soil $\mathrm{Pb}$

530 isotope ratio dataset (Figure 6). However, it is also clear from the position of the majority of the soil data in

531 Figure 6 that the $\mathrm{Pb}$ smelter cannot serve as a single 'industrial-Pb' source in Egypt and must be regarded

532 as a contributory factor. Figure 6 clearly indicates that a more general pool of (non-petrol) 'industrial-Pb' in

533 Egypt must have a $\mathrm{Pb}$ isotope signature closer to that of Egyptian geogenic- $\mathrm{Pb}$.

534

535

536

537

538

539

540

541

542

543

544

545 
546

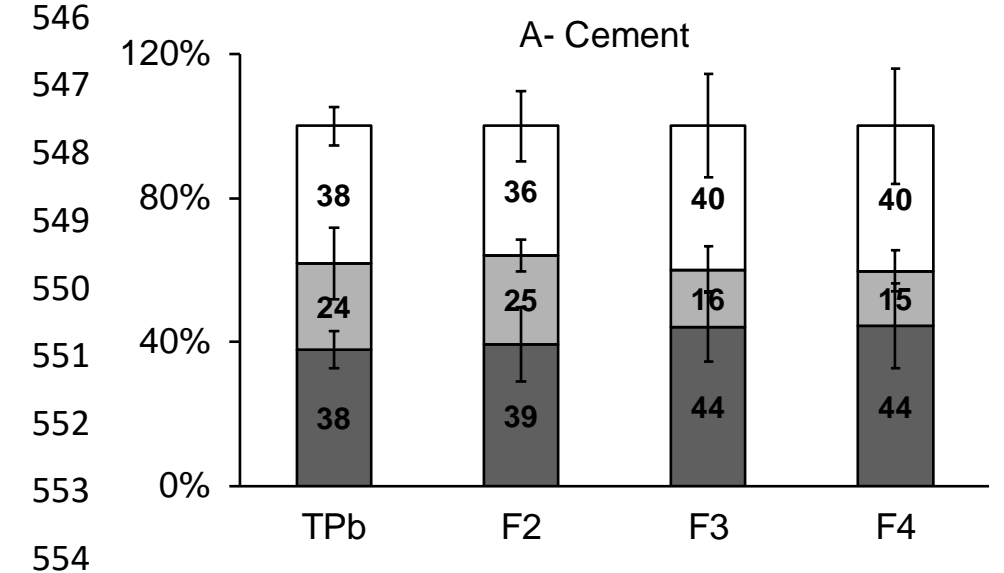

554

555

556

557

558

559

560

561

562

563

564

565

566

567

568

569

570

571

572

573

574

575

576

577

578

C- Urban

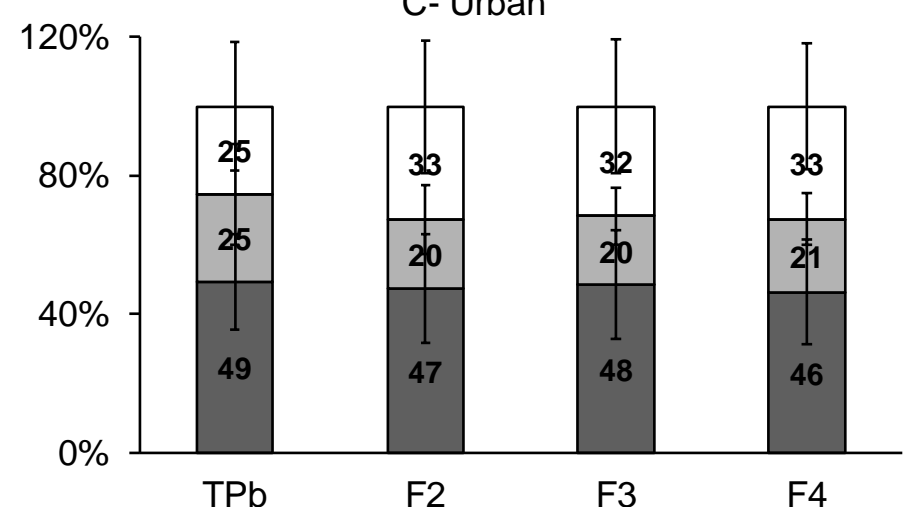

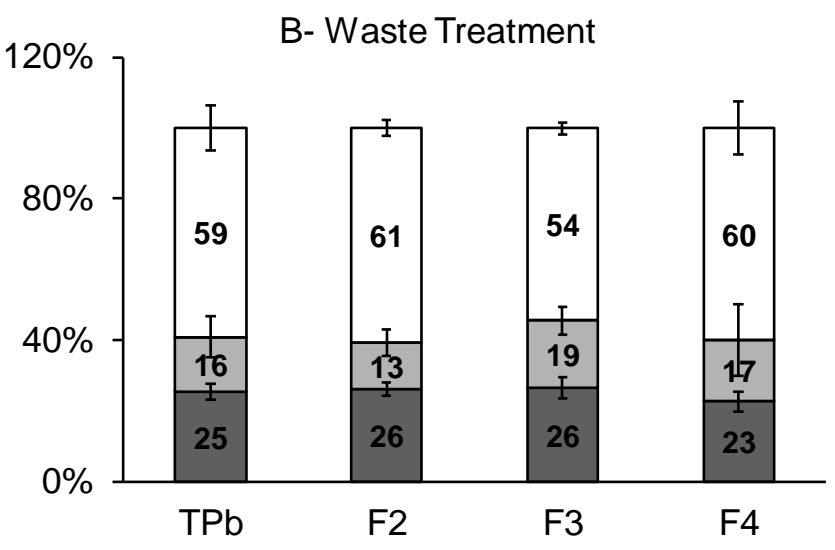

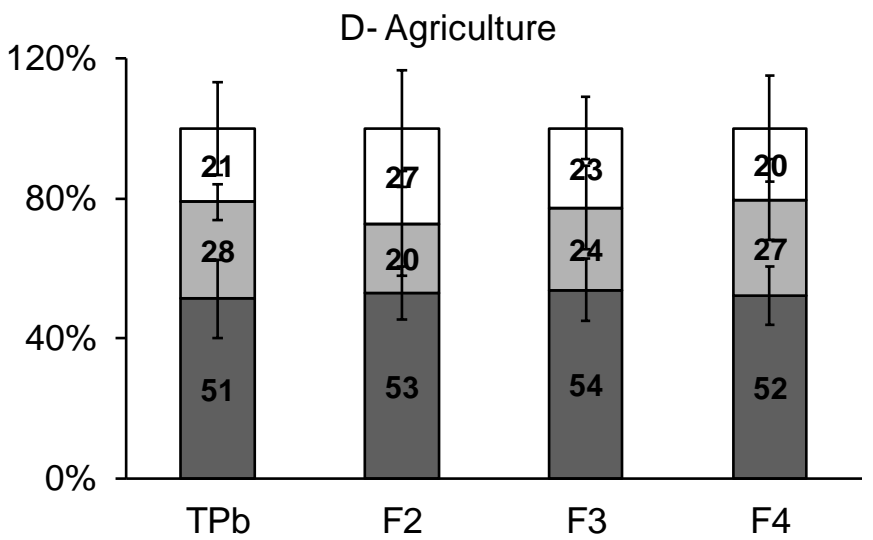

E- Background

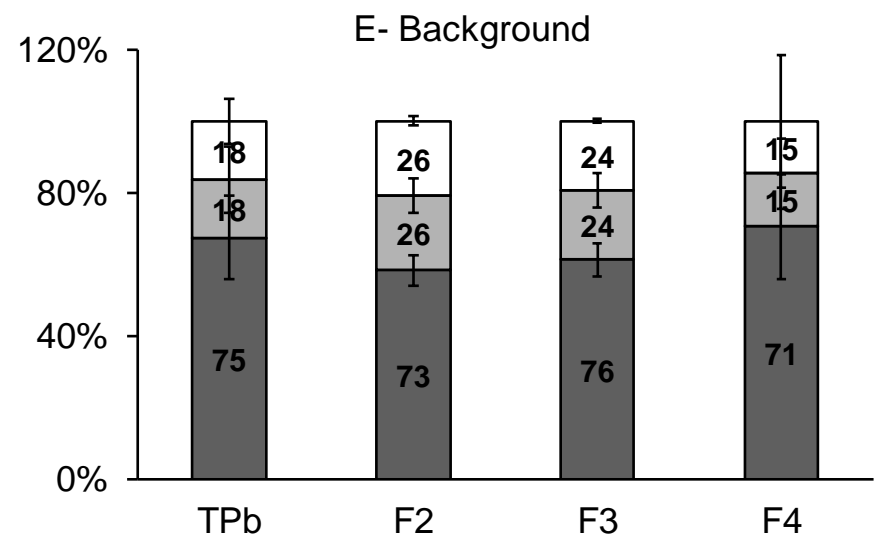

Figure 5. Proportion (\%) of petrol- $\mathrm{Pb}$ (white boxes), industrial- $\mathrm{Pb}$ (light grey boxes) and geogenic- $\mathrm{Pb}$ (dark grey boxes) in the total soil $\mathrm{Pb}(\mathrm{TPb})$ and the non-residual fractions F2, F3 and F4 in all sampling locations excluding the $\mathrm{SH}-\mathrm{I}$ (lead smelter) samples. Industrial-Pb signature was modelled by Solver from Eq. 3 and Eq. 4 with the hypothesis that all end-members isotopic signatures are locate at the periphery of the dataset. Numbers inside the boxes represent the proportion (\%) of each fraction to total $\mathrm{Pb}$ in the respective soil phase. Error bars represent the standard deviation between soils from the same location or soil type. 


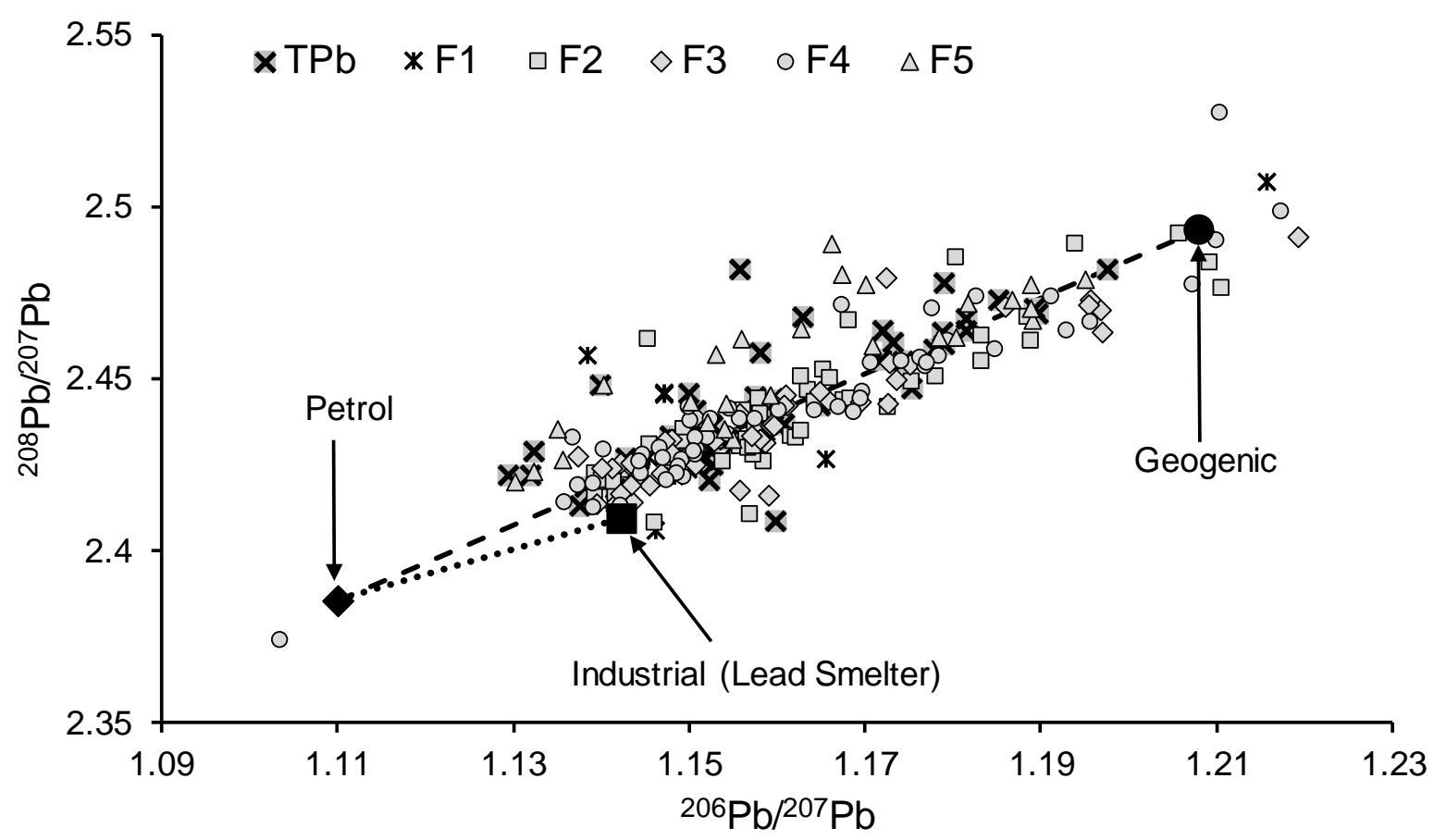

579

580

581

582

583

584

585

586

587

588

589

590

591

592

593

594

595

Figure 6. Anthropogenic- $\mathrm{Pb}$ isotopic ratios $\left({ }^{206} \mathrm{~Pb} / 207 \mathrm{~Pb}\right.$ vs $\left.{ }^{208} \mathrm{~Pb} / 207 \mathrm{~Pb}\right)$ of the whole soil and all five SEP fractions, in all soil samples. Petrol- $\mathrm{Pb}$ (black diamond), industrial-Pb (black square) and geogenic- $\mathrm{Pb}$ (black circle) signatures are also shown as possible end members. F5 fraction signatures are shown for samples where $\mathrm{F} 5-\mathrm{Pb}$ is $\geq 40 \%$ of total soil $\mathrm{Pb}(\mathrm{TPb})$. Dashed line in the mixing line between petrol- $\mathrm{Pb}$ and geogenic- $\mathrm{Pb}$ signatures while the dotted line is the mixing line between petrol- $\mathrm{Pb}$ and industrial- $\mathrm{Pb}$ (lead smelter). 


\section{Conclusions}

597 The concentrations of total soil $\mathrm{Pb}(\mathrm{TPb})$ in most of the studied soils were generally low and ranged around

598 the background and crustal Pb levels of $\sim 5$ and $14 \mathrm{mg} \mathrm{kg}^{-1}$, respectively. Substantially elevated TPb levels 599 were only found in two industrial locations around a closed lead smelter $\left(\mathrm{SH}-\mathrm{l} ; \sim 16201 \mathrm{mg} \mathrm{kg}^{-1}\right)$ and a 600 waste water treatment facility (CA-I; $171 \mathrm{mg} \mathrm{kg}^{-1}$ ), and in two urban locations around major motorways 601 within Cairo (CA-U; 160 $\mathrm{mg} \mathrm{kg}^{-1}$ ) and Alexandria (AX-U; $83 \mathrm{mg} \mathrm{kg}^{-1}$ ).

602 The residual fraction (F5-Pb) was the largest single fraction (38-63\%) in all the studied locations with the 603 exception of $\mathrm{SH}-\mathrm{I}$ and $\mathrm{CA}-\mathrm{I}$ sites which were dominated by the carbonate (F2-Pb; 44\%) and organic (F4$604 \mathrm{~Pb} ; 61 \%)$ fractions, respectively. Exchangeable $\mathrm{Pb}(\mathrm{F} 1-\mathrm{Pb})$ was only detectable in two locations: $\mathrm{SH}-\mathrm{I}(1 \%$ $\left.605 \mathrm{TPb} ; 162 \mathrm{mg} \mathrm{kg}^{-1}\right)$ and $\mathrm{CA}-\mathrm{U}\left(0.3 \% \mathrm{TPb} ; 1.6 \mathrm{mg} \mathrm{kg}^{-1}\right)$. Although this may suggest that the current risk 606 of releasing considerable amounts of available $\mathrm{Pb}$ is exclusive to $\mathrm{SH}-\mathrm{I}$ site (lead smelter), $\mathrm{Pb}$ in the other 3 607 non-residual fractions, in all locations including SH-I, may become available with any change in the soil $608 \mathrm{Eh} / \mathrm{pH}$ conditions. For example, in location CA-I (waste water treatment), if the conditions become more 609 oxidizing e.g. due to the waste treatment operations, the large organic ( $\mathrm{F} 4-\mathrm{Pb})$ pool will be released in 610 available forms. Therefore, in the four locations with elevated TPb levels (SH-I, CA-I, CA-U and AX-U), 611 despite their low/undetectable exchangeable- $\mathrm{Pb}$, careful consideration should be taken to avoid mobilizing 612 hazardous amounts of $\mathrm{Pb}$ to the surrounding environments.

613 The non-residual $\mathrm{Pb}$ isotopic signatures $\left(\mathrm{F} 1-\mathrm{F} 4 ;{ }^{206} \mathrm{~Pb} /{ }^{207} \mathrm{~Pb}\right)$ were dependent on the $\mathrm{Pb}$ source and level 614 of contamination; however, they displayed very similar patterns between the non-residual fractions (F2 $615 \mathrm{~F} 4)$. Similarly, the relative contribution of petrol- $\mathrm{Pb}$ to the non-residual $\mathrm{Pb}$ pools varied considerably 616 between sampling locations and was apparently controlled by the concentration of TPb despite being 617 almost identical in all the non-residual fractions (F2 - F4). This suggests no apparent difference in chemical 618 affinity of any given anthropogenic- $\mathrm{Pb}$ source for specific non-residual fractions in soil. Any initial source619 dependent distribution within the active soil fractions, following application to the soil, has apparently 620 disappeared with time.

621 It was not possible to identify a single 'third $\mathrm{Pb}$ source' to explain the distribution of $\mathrm{Pb}$ isotope ratios. A 622 major source, the $\mathrm{Pb}$ smelter in Cairo-Shubra, appeared to fall on the periphery of the dataset and could 
623 be a significant contributor to $\mathrm{Pb}$ contamination in the country. However, removal of an assumed 624 background geogenic source produced a dataset in which the majority of $\mathrm{Pb}$ isotope ratios fell beyond the 625 range covered by the petrol and smelter sources. The suggestion is therefore that the majority of 626 'contaminant $\mathrm{Pb}$ ' in Egypt has an isotopic signature close to that of geogenic $\mathrm{Pb}$.

627

628 Acknowledgments

629 Waleed Shetaya acknowledges a postdoctoral fellowship (at the University of Nottingham, UK) funded by 630 the Egyptian Government.

631

632 Conflicts of Interest

633 The authors declare no conflicts of interest.

634

635 Appendix A. Supplementary data

636

637

638

639

640

641

642

643 


\section{References}

645

646

647

648

649

650

651

652

653

654

655

656

657

658

659

660

661

662

663

664

665

666

667

668

669

670

671

672

673

674

675

676

677

678

679
Atkinson, N. R., Bailey, E. H., Tye, A. M., Breward, N. \& Young, S. D. 2011. Fractionation of lead in soil by isotopic dilution and sequential extraction. Environmental Chemistry, 8, 493-500.

Bacon, J. R., Farmer, J. G., Dunn, S. M., Graham, M. C. \& Vinogradoff, S. I. 2006. Sequential extraction combined with isotope analysis as a tool for the investigation of lead mobilisation in soils: Application to organic-rich soils in an upland catchment in scotland. Environmental pollution, 141, 469-481.

Blum, J. D. \& Bergquist, B. A. 2007. Reporting of variations in the natural isotopic composition of mercury. Analytical and Bioanalytical Chemistry, 388, 353-359.

Brookins, D. G. 2012. Eh-ph diagrams for geochemistry, Springer Science \& Business Media.

Chenery S. R., Izquierdo M., Marzouk E., Klinck B., Palumbo-Roe B., Tye A. M. 2012. Soil-plant interactions and the uptake of $\mathrm{Pb}$ at abandoned mining sites in the Rookhope catchment of the $\mathrm{N}$. Pennines, UK-a Pb isotope study. Science of the Total Environment, 433, 547-560.

Cheng, H. \& Hu, Y. 2010. Lead (pb) isotopic fingerprinting and its applications in lead pollution studies in china: A review. Environmental Pollution, 158, 1134-1146.

Clevenger, T. E., Saiwan, C. \& Koirtyohann, S. 1991. Lead speciation of particles on air filters collected in the vicinity of a lead smelter. Environmental science \& technology, 25, 1128-1133.

Cotter-Howells, J. \& Thornton, I. 1991. Sources and pathways of environmental lead to children in a derbyshire mining village. Environmental Geochemistry and Health, 13, 127-135.

Degryse, F., Smolders, E. \& Parker, D. 2009. Partitioning of metals (cd, co, cu, ni, pb, zn) in soils: Concepts, methodologies, prediction and applications-a review. European Journal of Soil Science, 60, 590-612.

Drummond, L. \& Maher, W. 1995. Determination of phosphorus in aqueous-solution via formation of the phosphoantimonylmolybdenum blue complex - reexamination of optimum conditions for the analysis of phosphate. Analytica Chimica Acta, 302, 69-74.

Emsley, J. 2011. Nature's building blocks: An az guide to the elements, Oxford University Press.

Foster, R. L. \& Lott, P. F. 1980. X-ray diffractometry examination of air filters for compounds emitted by lead smelting operations. Environmental Science \& Technology, 14, 1240-1244.

Harrison, R. M., Laxen, D. P. \& Wilson, S. J. 1981. Chemical associations of lead, cadmium, copper, and zinc in street dusts and roadside soils. Environmental Science \& Technology, 15, 1378-1383.

Hassan, S. K., El-Abssawy, A. A., Abdel-Maksoud, A. S., Abdou, M. H. \& Khoder, M. I. 2013. Seasonal behaviours and weekdays/weekends differences in elemental composition of atmospheric aerosols in cairo, egypt. Aerosol and Air Quality Research, 13, 1552-1562.

Hassanien, M. \& Horvath, A. 1999. Lead risk assessment for children in hungary by predicting their blood lead levels using us epa integrated exposure uptake biokinetic model. Central European journal of public health, 7, 155-159. 
Hassanien, M. A., Rieuwerts, J., Shakour, A. \& Bittó, A. 2001. Seasonal and annual variations in air concentrations of $\mathrm{pb}, \mathrm{cd}$ and pahs in cairo, egypt. International journal of environmental health research, 11, $13-27$.

Izquierdo, M., Tye, A. \& Chenery, S. 2012. Sources, lability and solubility of pb in alluvial soils of the river trent catchment, uk. Science of the Total Environment, 433, 110-122.

Komárek, M., Ettler, V., Chrastný, V. \& Mihaljevič, M. 2008. Lead isotopes in environmental sciences: A review. Environment International, 34, 562-577.

Kostka, J. E. \& Luther, G. W. 1994. Partitioning and speciation of solid phase iron in saltmarsh sediments. Geochimica et Cosmochimica Acta, 58, 1701-1710.

Labib, M. W., Safar, Z. \& Khalil, M. H. 2003. Lead emission inventory in the greater cairo area during the life time of caip. AWMA paper, 70137.

Lee, P.-K. \& Yu, S. 2016. Lead isotopes combined with a sequential extraction procedure for source apportionment in the dry deposition of asian dust and non-asian dust. Environmental Pollution, 210, 6575.

Li, X. \& Thornton, I. 2001. Chemical partitioning of trace and major elements in soils contaminated by mining and smelting activities. Applied geochemistry, 16, 1693-1706.

Luo, X.-S., Xue, Y., Wang, Y.-L., Cang, L., Xu, B. \& Ding, J. 2015. Source identification and apportionment of heavy metals in urban soil profiles. Chemosphere, 127, 152-157.

Mao, L. C., Bailey, E. H., Chester, J., Dean, J., Ander, E. L., Chenery, S. R. \& Young, S. D. 2014. Lability of pb in soil: Effects of soil properties and contaminant source. Environmental Chemistry, 11, 690-701.

Marzouk, E. R., Chenery, S. R. \& Young, S. D. 2013a. Measuring reactive metal in soil: A comparison of multi-element isotopic dilution and chemical extraction. European Journal of Soil Science, 64, 526-536.

Marzouk, E. R., Chenery, S. R. \& Young, S. D. 2013b. Predicting the solubility and lability of zn, cd, and $\mathrm{pb}$ in soils from a minespoil-contaminated catchment by stable isotopic exchange. Geochimica Et Cosmochimica Acta, 123, 1-16.

Mcbride, M. 1994. Environmental soil chemistry. Oxford University Press, New York.

Meers, E., Du Laing, G., Unamuno, V., Ruttens, A., Vangronsveld, J., Tack, F. M. \& Verloo, M. G. 2007. Comparison of cadmium extractability from soils by commonly used single extraction protocols. Geoderma, 141, 247-259.

Mohamed, E. F., El-Hashemy, M. A., Abdel-Latif, N. M. \& Shetaya, W. H. 2015. Production of sugarcane bagasse-based activated carbon for formaldehyde gas removal from potted plants exposure chamber. Journal of the Air \& Waste Management Association, 65, 1413-1420.

Monna, F., Lancelot, J., Croudace, I. W., Cundy, A. B. \& Lewis, J. T. 1997. Pb isotopic composition of airborne particulate material from france and the southern united kingdom: Implications for pb pollution sources in urban areas. Environmental Science \& Technology, 31, 2277-2286.

Murphy, S. 1992. Smelting residues from boles and simple smeltmills. Boles and smeltmills, 43-47.

Nasralla, M. \& Ali, E. 1984. Lead, cadmium and zinc around traffic roads. Egyptian J. Occupat. Med, 8, 197-210. 
Needleman, H. L. \& Bellinger, D. 1991. The health effects of low level exposure to lead. Annual Review of Public Health, 12, 111-140.

Olsen, S. R., Cole, C. V., Watanabe, F. S. \& Dean, L. A. 1954. Estimation of available phosphorus in soils by extraction with sodium bicarbonate. U.S. Dep. of Agric. Circ, 939.

Rizk, H. F. \& Khoder, M. I. 2001. Decreased lead concentration in cairo atmosphere due to use of unleaded gasoline. Central European Journal of Occupational and Environmental Medicine Hungary.

Roebbert, Y., Rabe, K., Lazarov, M., Schuth, S., Schippers, A., Dold, B. \& Weyer, S. 2018. Fractionation of fe and cu isotopes in acid mine tailings: Modification and application of a sequential extraction method. Chemical Geology, 493, 67-79.

Safar, Z., Labib, M. W., Lotfi, W. \& Khalil, M. H. 2014. Characterization of contamination around the largest lead smelter in egypt carried out through a cooperation program between USA and egypt. Field Actions Science Reports. The journal of field actions, 7.

Safar, Z. S. \& Labib, M. W. 2010. Assessment of particulate matter and lead levels in the greater cairo area for the period 1998-2007. Journal of advanced research, 1, 53-63.

Sastre, J., Rauret, G. \& Vidal, M. 2006. Effect of the cationic composition of sorption solution on the quantification of sorption-desorption parameters of heavy metals in soils. Environmental pollution, 140, 322-339.

Shaheen, S. M. 2009. Sorption and lability of cadmium and lead in different soils from egypt and greece. Geoderma, 153, 61-68.

Shakour, A. \& El-Taieb, N. 1994. Effect of atmospheric lead exposure on urban children. Egyptian J Occup Med, 18, 37-47.

Shetaya, W. H., Marzouk, E. R., Mohamed, E. F., Elkassas, M., Bailey, E. H. \& Young, S. D. 2018. Lead in egyptian soils: Origin, reactivity and bioavailability measured by stable isotope dilution. Science of The Total Environment, 618, 460-468.

Shetaya, W. H., Osterwalder, S., Bigalke, M., Mestrot, A., Huang, J.-H. \& Alewell, C. 2017. An isotopic dilution approach for quantifying mercury lability in soils. Environmental Science \& Technology Letters, 4, 556-561.

Sparks, D. L. 2003. Environmental soil chemistry, Academic Press, An imprint of Elsevier Science, California, USA.

Tack, F. \& Verloo, M. G. 1995. Chemical speciation and fractionation in soil and sediment heavy metal analysis: A review. International Journal of Environmental Analytical Chemistry, 59, 225-238.

Tessier, A., Campbell, P. G. C. \& Bisson, M. 1979. Sequential extraction procedure for the speciation of particulate trace-metals. Analytical Chemistry, 51, 844-851.

Teutsch, N., Erel, Y., Halicz, L. \& Banin, A. 2001. Distribution of natural and anthropogenic lead in mediterranean soils. Geochimica et Cosmochimica Acta, 65, 2853-2864.

Tipping, E., Thompson, D., Ohnstad, M. \& Hetherington, N. 1986. Effects of ph on the release of metals from naturally-occurring oxides of $\mathrm{mn}$ and fe. Environmental Technology, 7, 109-114.

Tongtavee, N., Shiowatana, J., Mclaren, R. G. \& Gray, C. W. 2005. Assessment of lead availability in contaminated soil using isotope dilution techniques. Science of the Total Environment, 348, 244-256. 
758

759

760

761

762

763

764
Veysseyre, A. M., Bollhöfer, A. F., Rosman, K. J., Ferrari, C. P. \& Boutron, C. F. 2001. Tracing the origin of pollution in french alpine snow and aerosols using lead isotopic ratios. Environmental science \& technology, 35, 4463-4469.

Who 2010. Exposure to lead: A major public health concern. Preventing disease through healthy environments. Geneva, World Health Organization (http://www.who.int/ipcs/features/lead..pdf) 6.

Young, S. D., Tye, A., Carstensen, A., Resende, L. \& Crout, N. 2000. Methods for determining labile cadmium and zinc in soil. European Journal of Soil Science, 51, 129-136. 